\title{
Neurogenesis in the Adult Avian Song-Control System
}

\author{
Eliot A. Brenowitz and Tracy A. Larson \\ Departments of Biology and Psychology, University of Washington, Seattle, Washington 98195 \\ Correspondence: eliotb@uw.edu
}

\begin{abstract}
New neurons are added throughout the forebrain of adult birds. The song-control system is a model to investigate the addition of new long-projection neurons to a cortical circuit that regulates song, a learned sensorimotor behavior. Neuroblasts destined for the song nucleus HVC arise in the walls of the lateral ventricle, and wander through the pallium to reach HVC. The survival of new HVC neurons is supported by gonadally secreted testosterone and its downstream effectors including neurotrophins, vascularization, and electrical activity of postsynaptic neurons in nucleus RA (robust nucleus of the arcopallium). In seasonal species, the HVC $\rightarrow$ RA circuit degenerates in nonbreeding birds, and is reconstructed by the incorporation of new projection neurons in breeding birds. There is a functional linkage between the death of mature HVC neurons and the birth of new neurons. Various hypotheses for the function of adult neurogenesis in the song system can be proposed, but this remains an open question.
\end{abstract}

ong behavior in oscine birds is regulated by $\checkmark$ a network of pallial and striatal nuclei. The song-control system shows extensive plasticity in adults, including ongoing neurogenesis in several nuclei (Brenowitz 2008). The addition of new neurons to the adult brain of higher vertebrates was first suggested by the pioneering studies of Altman and Das (1965) and Kaplan and Hinds (1977). They reported that labeled cells were present in the dentate gyrus (DG) of rats following the injection of ${ }^{3} \mathrm{H}$-thymidine. Their claims, however, met with skepticism and the neuronal identity of the new cells that they observed was called into question (Gross 2000). In an influential study, Rakic (1985) injected adult rhesus monkeys with ${ }^{3} \mathrm{H}$-thymidine and reported that, "all neurons of the rhesus monkey brain are generated during prenatal and early postnatal life." The study of neuronal addition to the adult brain, was subsequently dropped for $\sim 20$ years in the face of the dogma that neurogenesis was largely completed by birth (Gross 2000). This prevailing view only started to be overturned when Nottebohm and colleagues published a series of studies showing that new cells are added to the cortical-like song nucleus HVC (Fig. 1) of adult canaries (Serinus canarius) (Goldman and Nottebohm 1983). These new cells have neuronal morphology, some of these cells fire action potentials in response to sound (Paton and Nottebohm 1984), receive synaptic input (Burd and Nottebohm 1985), may synapse on neurons in the efferent robust nucleus of the arcopallium (RA)

Editors: Fred H. Gage, Gerd Kempermann, and Hongjun Song

Additional Perspectives on Neurogenesis available at www.cshperspectives.org

Copyright (C) 2015 Cold Spring Harbor Laboratory Press; all rights reserved; doi: 10.1101/cshperspect.a019000

Cite this article as Cold Spring Harb Perspect Biol 2015;7:a019000 
E.A. Brenowitz and T.A. Larson

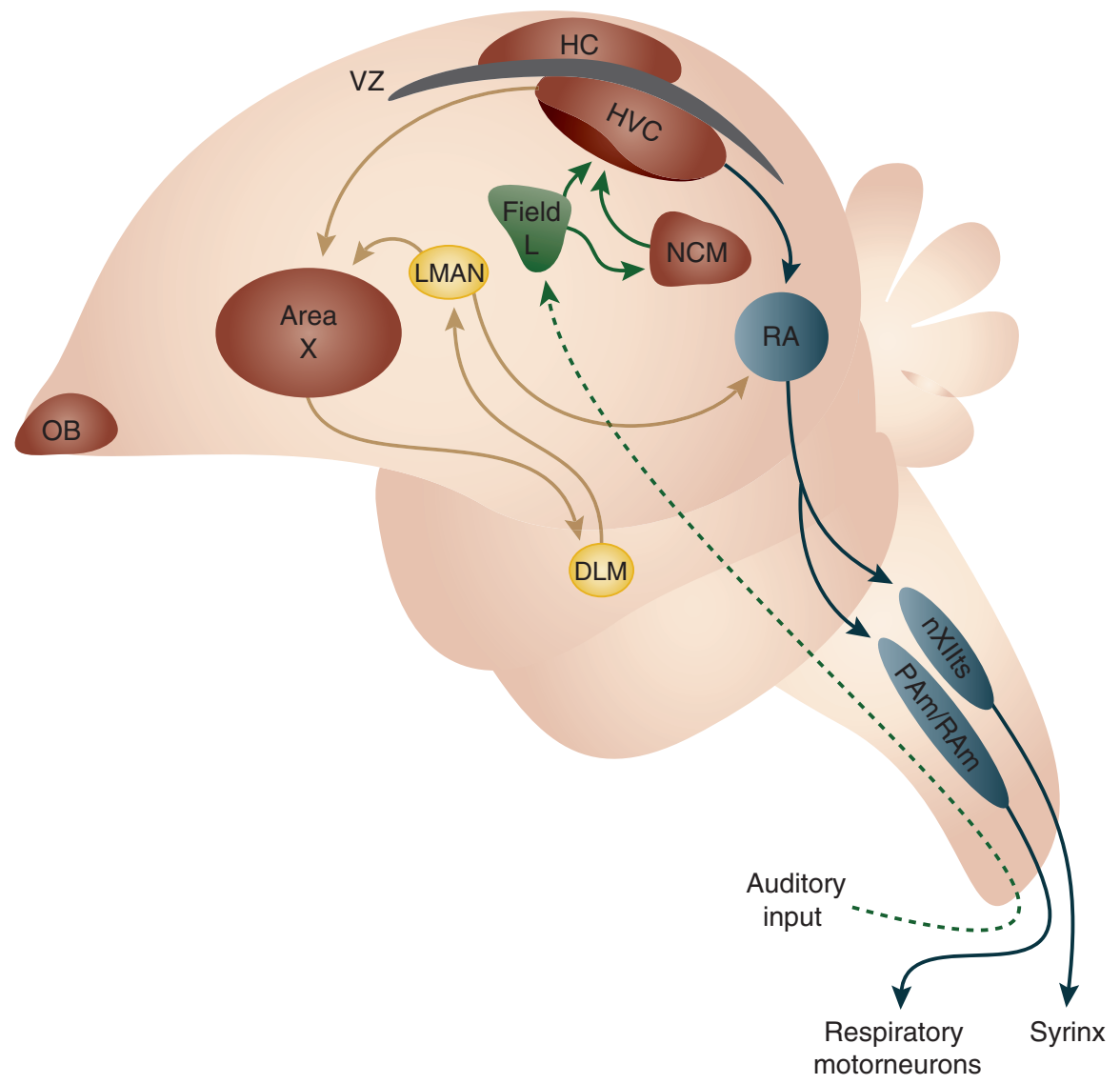

Figure 1. A schematic of the neurogenic regions in the avian brain overlaid on the avian song circuits. Neurogenic regions are shown in red. Note the proximity of HVC (and hippocampus [HC]) to the ventricular zone (VZ). A schematic version of the motor pathway for song production is shown in blue. A schematic of the ascending auditory pathway is shown in green. The dotted line indicates an indirect route through many nuclei of the ascending auditory pathway leading to field $\mathrm{L}$ in the telencephalon. The anterior forebrain circuit for song learning and plasticity is shown in yellow. NCM, Caudomedial nidopallium; RA, arcopallium; LMAN, lateral magnocellular nucleus of the anterior neostriatum; OB, olfactory bulb; DLM, dorsolateral medial; PAm, parambigualis; RAm, retroambigualis

(Alvarez-Buylla et al. 1990), and express neuron-specific proteins (Barami et al. 1995). Together, these studies in songbirds showed that new neurons are born and incorporated into functional circuits in the brains of adults of higher vertebrates (Nottebohm 2004). This research on adult neurogenesis in songbirds stimulated investigators to re-examine this topic in mammals. It soon became clear that new neurons are added throughout life to the DG and olfactory bulb of mammals including humans (Cameron and Gould 1994; Gould et al. 1997, 1999a; Lim et al. 1997; Eriksson et al. 1998). Because of these initial confirmatory reports, there has been explosive growth in study of the mechanisms and functions of adult neurogenesis in the mammalian DG and olfactory bulb.

Birds continue to be a productive model for the study of neurogenesis in the adult brain, as discussed below. In this article, we will focus on neurogenesis in the song-control system as this is the most intensively studied model in birds. (For a review of neurogenesis in the avian hippocampus $[\mathrm{HC}]$, see Barnea and Pravosudov 
2011.) We will discuss the mechanisms of neurogenesis in the song system, intrinsic and extrinsic factors that influence neuronal addition, a linkage between cell death and neurogenesis, seasonal plasticity, and consider potential functions of adult neurogenesis.

\section{WHY STUDY ADULT NEUROGENESIS IN BIRDS?}

The birdsong system offers several advantages as a model:

1. Unlike mammals, in which substantial neurogenesis is primarily limited to two regions of the brain (HC and olfactory bulb), new neurons are added throughout most of the avian telencephalon, and this form of plasticity, therefore, seems to be a fundamental feature of the forebrain in birds (AlvarezBuylla et al. 1994).

2. The song nuclei that incorporate new neurons in adult birds, HVC, and area X (a basal ganglia homolog) are dedicated to the regulation of song, a learned sensorimotor behavior. Placing adult neurogenesis in these regions into a functional context is, therefore, relatively straightforward (e.g., Brown et al. 1999; Gould et al. 1999b; Malberg et al. 2000; Morris 2006; Abrous and Wojtowicz 2008; Clelland et al. 2009; Konkel and Cohen 2009).

3. The level of ongoing neurogenesis in the avian brain is higher by at least an order of magnitude than that seen in mammalian brains. In birds, $0.1 \%-0.7 \%$ of all HVC neurons and $0.15 \%-0.37 \%$ of hippocampal neurons are newly recruited per day on average, depending on the species (Gahr et al. 2002). In contrast, it is estimated that $0.02 \%$ of total hippocampal granule cells in mature macaque monkeys, and $0.2 \%$ in 10 -wk-old rats, are generated per day (Cameron and McKay 2001; Jabès et al. 2010). Using ${ }^{14} \mathrm{C}$ dating as a measure of postnatal cell proliferation in human brains, Spalding et al. (2013) estimated that $0.004 \%$ of neurons in the DG turn over each day. In mammals, "adult neurogenesis is not a mass phenomenon but appears to make a qualitative rather than quantitative contribution" (Gage et al. 2008). The higher level of neuronal addition in birds makes it more tractable for experimental manipulation, and suggests that ongoing neurogenesis is a quantitative phenomenon in birds.

4. Neuronal addition to the mature DG is offset by cell death, and total neuron number does not change throughout adult life (Jabès et al. 2010). Seasonally breeding songbirds, however, show pronounced seasonal cycles of a large increase in neuronal number in HVC of breeding adults because of neurogenesis, followed by a decrease in nonbreeding birds owing to apoptosis (see below). This seasonal pattern facilitates relating changes in behavior to the addition or loss of neurons.

5. Most of the new neurons added to the adult HVC have long axons that project $4 \mathrm{~mm}$ or more to synapse on target cells in RA (Alvarez-Buylla et al. 1990; Scotto-Lomassese et al. 2007). New neurons added to the olfactory bulb in mammals, in contrast, are interneurons (Lledo et al. 2006; De Marchis et al. 2007), and those added to the DG are granule cells that synapse locally on the hippocampal hilus and CA3 (Toni et al. 2008). HVC, therefore, provides a unique model for investigating the incorporation of new neurons into long-range neural circuits, and facilitates manipulations of target cells to examine postsynaptic influences on the addition of new afferent neurons (e.g., Larson et al. 2013).

6. There are $\sim 4000$ species of songbirds. The species studied thus far all learn to sing, possess the same conserved network of hormone-sensitive brain nuclei that regulate song, and show adult neurogenesis in HVC and area X (Brenowitz 1997, 2008; Wilbrecht and Kirn 2004; Jarvis 2009; Barnea and Pravosudov 2011). There is much variation among taxa in whether song learning is restricted to juveniles or continues into adulthood, the number of songs learned, plasticity of adult song, and sexual patterns of song behavior (Beecher and Brenowitz 2005). This species diversity provides rich opportu- 
nities for comparative studies to test the role of neurogenesis in regulating different aspects of learned song behavior.

\section{BASIC PROCESSES}

\section{Neurogenic Niches and Proliferation}

Proliferative cells that give rise to new neurons and glia reside in "hotspots" in the walls of the lateral ventricle in the brain (Fig. 1) (AlvarezBuylla et al. 1990, 2002; Vellema et al. 2010). Mapping studies in birds show that proliferating cells reside at the lateral and tectal ventricles in the adult canary (S. canarius) brain (AlvarezBuylla et al. 1990; Vellema et al. 2010). Cell proliferation at the ventrolateral and the dorsomedial walls of the lateral ventricles account for $93 \%$ and $6 \%$ of the total number of proliferating cells, respectively (Alvarez-Buylla et al. 1990). Less than $1 \%$ of the total number of all cells proliferating in the canary brain arise at the tectal ventricle (Alvarez-Buylla et al. 1990). The proliferating cells in the ventricular zone (VZ) generate multiple cell types. Tissue explant cultures containing the ependyma of the lateral ventricle give rise to both radial glia and new neurons that differentiate and form synapses within 2 wk (Goldman 1990; Goldman et al. 1993, 1996). Neural stem-cell-derived radial glial cells are thought to serve as the neural progenitors in the adult bird brain, although this remains a topic of debate (Gray and Sanes 1992; Goldman et al. 1996; Alvarez-Buylla et al. 2002).

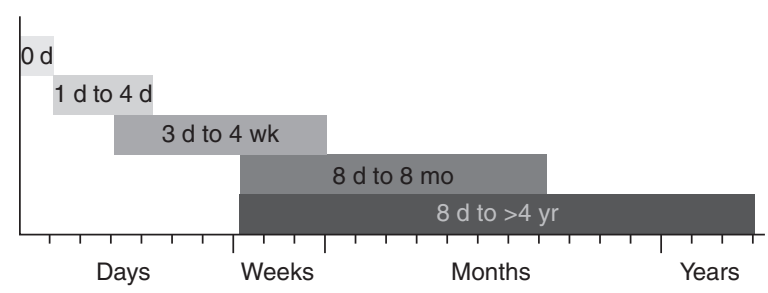

Figure 2. A timeline of the processes of avian neurogenesis and the proportion of new neurons that persist through each of these processes. The timeline is based on the work of Alvarez-Buylla and Nottebohm (1988), Barami et al. (1994), and Scott et al. (2012). The percentages of survival through the various processes of avian neurogenesis are based on the findings of Kirn et al. (1991, 1999), Barnea and Nottebohm (1994), Nottebohm et al. (1994), Scott and Lois (2007), and Walton et al. (2012). VZ, Ventricular zone.

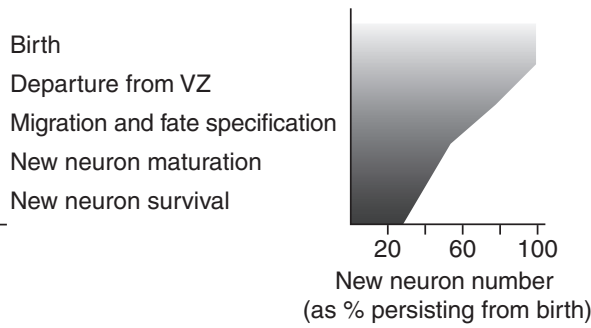

\section{Migration of Neuroblasts}

Proper migration and incorporation of new neurons is necessary for them to be integrated into functional neural circuits. In birds, the departure of neuroblasts and newly differentiated neurons from the neurogenic niche begins 1 to $4 \mathrm{~d}$ after birth (Fig. 2) (Alvarez-Buylla and Nottebohm 1988; Barami et al. 1994). These new cells must migrate over long distances to reach most of their destinations in the telencephalon. New HVC neurons migrate over 1 to 2 wk (Alvarez-Buylla and Nottebohm 1988) by one of two modes: radial or undirected wandering.

Neuroblasts with a classical bipolar migratory phenotype are generally associated with the fibers of ependymally derived radial glia, both in vitro (Goldman et al. 1993) and in vivo (AlvarezBuylla and Nottebohm 1988; Scott et al. 2012). About $30 \%$ of new HVC neurons are associated with radial glia (Scott et al. 2012). Typical radial glial cells reside in the $\mathrm{VZ}$ at the lateral ventricles and project their processes mediolaterally (Alvarez-Buylla and Nottebohm 1988). Association of ${ }^{3} \mathrm{H}$-thymidine-positive cells with radial fibers suggests that these processes provide the scaffolding on which some neuroblasts migrate through the adult avian brain (Alvarez-Buylla and Nottebohm 1988). Radial glia also provide trophic support for the migrating neuroblasts. Insulin-like growth factor-1 (IGF-1) is expressed by radial glia cells and their fibers, and promotes the migration of neuroblasts (Jiang et al. 1998).

Most of the neuroblasts $(\sim 70 \%)$ that give rise to new HVC neurons adopt a multipolar

\footnotetext{
New neuron number (as \% persisting from birth)
} 
phenotype and follow a wandering, tortuous route with frequent changes in direction rather than a straight path through HVC during migration (Scott et al. 2012). Movement is produced by translocation of the cell body along one of the processes that extends from the soma. Wandering may continue for several days, during which the cell may travel several hundred micrometers. These multipolar cells differentiate into neurons once they reach their destination (Scott et al. 2012).

It is unclear whether bipolar and multipolar neuroblasts represent different stages of migration of the same cells or distinct neuronal types. Neuroblasts may initially migrate away from the VZ along radial glial fibers, and then transition to wandering during the final stages of migration (Alvarez-Buylla and Nottebohm 1988; Scott et al. 2012). Alternatively, bipolar and multipolar neuroblasts may represent different neuronal types. Scott et al. (2012) suggest that this latter possibility is less likely, given the changes in phenotype, polarity, direction, and scaffolding observed in migrating neuroblasts in mammalian brains.

Postmigratory Maturation and Fate Specification

As early as $8 \mathrm{~d}$ following birth, new neurons that express neuronal markers but are not yet fully mature and functional can be found in HVC (Fig. 2) (Kirn et al. 1999). At the end of migration, these new neurons form close contact with the soma of mature HVC neurons (Burd and Nottebohm 1985). These new cells integrate into functional circuits, and form somatal contact with mature HVC interneurons and neurons that project to area $\mathrm{X}\left(\mathrm{HVC}_{\mathrm{X}}\right)$ and $\mathrm{RA}$ $\left(\mathrm{HVC}_{\mathrm{RA}}\right.$ ) (Fig. 2) (Kirn et al. 1999; Scott et al. 2012). These cellular interactions may provide a "stop" signal that terminates migration (Scott et al. 2012). Together, the new and mature neurons form clusters that may represent a functional unit (Kirn et al. 1999). The neurons within these clusters appear to be connected by gap junctions (Gahr and Garcia-Segura 1996). This coupling may allow $\mathrm{HVC}_{\mathrm{X}}$ neurons to entrain new $\mathrm{HVC}_{\mathrm{RA}}$ neurons to produce the appropri- ate motor pattern for song production (Alvarez-Buylla and Kim 1997).

Most or all of the new HVC neurons project to the afferent nucleus RA. It is unclear whether some neuroblasts differentiate into HVC interneurons (Scott and Lois 2007; Scotto-Lomassese et al. 2007). By 2 wk of age, these neurons can form synapses on RA neurons as shown by the uptake and retrograde transport from RA of tract tracers (Kirn et al. 1999). Although capable of forming synapses by $2 \mathrm{wk}$, nearly half of the new HVC neurons that will ultimately project to RA have not yet formed synapses even by $30 \mathrm{~d}$ following birth in adult canaries and zebra finches (Kirn et al. 1999; Scott and Lois 2007). By 8 mo, all new $\mathrm{HVC}_{\mathrm{RA}}$ neurons form synapses onto RA neurons in canaries (Kirn et al. 1999).

\section{Survival of Newly Generated Neurons}

Adult-born neurons in the avian brain persist for periods ranging from days to years. Between 2 and $3 \mathrm{wk}$ following birth, roughly half of all postmigratory neurons in HVC die (Fig. 2) (Kirn et al. 1999). In the HC of the adult blackcapped chickadee (Parus atricapillus), the number of ${ }^{3} \mathrm{H}$-thymidine-labeled neurons decreases between 6 and $10 \mathrm{wk}$ after birth (Barnea and Nottebohm 1994). The new neurons that persist through the initial culling can survive months (Kirn et al. 1991; Nottebohm et al. 1994) to years (Barnea and Nottebohm 1994; Walton et al. 2012), depending on their time of birth, location of incorporation, and other factors discussed below (Fig. 2). Given that the number of newly generated HVC neurons does not decrease significantly between 9 mo and $4 \mathrm{yr}$ in the zebra finch (Taeniopygia guttata) (Walton et al. 2012), it is possible that some adult-born neurons persist in HVC and other regions of the avian brain for the remainder of the bird's life.

\section{MOLECULAR AND PHYSIOLOGICAL MECHANISMS}

\section{Genomics}

Gene regulatory networks that control different aspects of neurogenesis and cell death have 


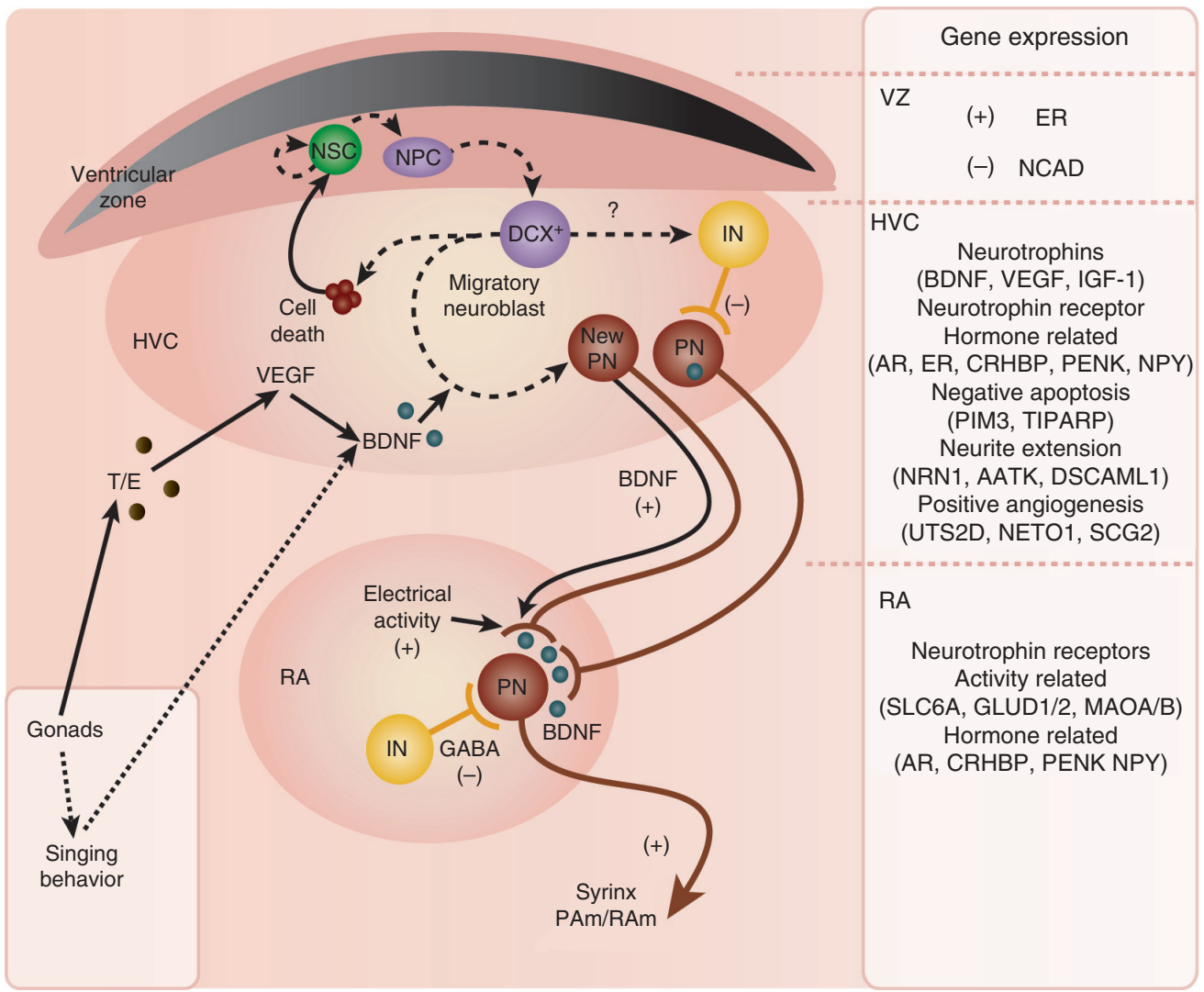

Figure 3. A schematic of the factors ranging from gene expression to behavior that influence the birth and migration of neuroblasts and the addition of new neurons to an HVC. The solid black lines indicate factors that positively influence the given cell, factor, or process to which it points. The dashed lines represent changes in cell process indicated (e.g., cell divisions and migration). The dotted lines represent indirect routes of influence (i.e., through other genes, factors, etc.). The breakout panel to the right summarizes patterns of gene expression in different brain regions that positively influence component processes of neurogenesis. In the ventricular zone (VZ), the $(+)$ indicates genes that promote proliferation, whereas the $(-)$ indicates genes the promote exit from the cell cycle. DCX ${ }^{+}$, Doublecortin-positive migratory neuroblast; IN, interneuron; NPC, neural progenitor cell; NSC, neural stem cell; PN, projection neuron. ER, endoplasmic reticulum; VEGF, vascular endothelial growth factor; BDNF, brain-derived neurotrophic factor; GABA, $\gamma$-aminobutyric acid; RA, arcopallium; PAm, parambigualis; RAm, retroambigualis.

been identified through the sequencing and analysis of the zebra finch genome and microarray analyses (Fig. 3) (Warren et al. 2010; Thompson et al. 2012). Thompson et al. (2012) identified 132 genes in HVC cells in adult male white-crowned sparrows (Zonotrichia leucophrys), which changed in expression between breeding and nonbreeding physiological conditions when compared with gene expression in RA, a nonneurogenic nucleus (Alvarez-Buylla et al. 1994). In general, genes that promote proliferation, angiogenesis, and neurite extension were up-regulated, whereas genes that support programmed cell death were down-regulated in HVC under breeding conditions. Specific genes that encode for neurotrophins known to promote neuronal migration, recruitment, and survival, including brain-derived neurotrophic factor (BDNF), IGF-1, and vascular endothelial growth factor (VEGF), were up-regulated in HVC cells under breeding conditions. 
Interactions of Steroid Hormones and Neurotrophins

Steroid sex hormones secreted by the gonads and synthesized de novo in the brain influence the survival of adult-born HVC neurons. The effects of hormones on avian neurogenesis are mediated by the expression of neurotrophic factors. Treatment of adult female canaries with exogenous testosterone ( $\mathrm{T}$ ) increases the number of new neurons added to HVC (Rasika et al. 1994). This effect of $\mathrm{T}$ on neuronal addition requires BDNF (Rasika et al. 1999). T treatment increases both BDNF mRNA and protein in HVC cells (Rasika et al. 1999; Wissman and Brenowitz 2009). Intracerebral infusion of recombinant BDNF (rBDNF) into HVC increased the number of new neurons by the same amount as did $\mathrm{T}$ treatment, whereas infusion of a BDNFblocking antibody prevented the T-induced increase in new neurons in HVC (Rasika et al. 1999). BDNF promotes neuronal addition to HVC during a discrete critical period. Infusion of rBDNF into HVC 14-20 d after the birth of new neurons increased the number of neurons that survived for at least $8 \mathrm{mo}$. Birds that were infused with BDNF either $4-10$ or $24-30 \mathrm{~d}$ after birth, however, showed the typical die-off of $50 \%$ of new HVC neurons by 4 mo (Nottebohm et al. 1994; Alvarez-Borda et al. 2004). These observations suggest that T-induced expression of BDNF increases the survival of newly generated neurons in $\mathrm{HVC}$, and that there is a sensitive period soon after new neurons first reach HVC when BDNF has this effect on neuronal survival.

The interaction between $\mathrm{T}$ and BDNF in adult neurogenesis is mediated by local angiogenesis in HVC. T treatment expands the microvasculature in HVC, including increases in the number of new endothelial cells, and the diameter, perimeter, and area of capillaries (Louissaint et al. 2002). In female canaries, this $\mathrm{T}$ treatment mediates these effects in HVC by up-regulating expression of both VEGF and its receptor Quek1/VEGF receptor 2 (R2) tyrosine kinase within $2 \mathrm{wk}$. Both the induction of VEGF and Quek1/VEGFR2 appear to be mediated by the metabolic conversion of $\mathrm{T}$ to $17 \beta$ - estradiol $\left(\mathrm{E}_{2}\right)$. Treatment of cultured HVC endothelial cells with $\mathrm{E}_{2}$, but not the androgenic metabolite 5- $\alpha$ dihydrotestosterone (DHT), increased Quek 1/VEGFR2 mRNA expression. Furthermore, systemic treatment of female canaries with $\mathrm{E}_{2}$-induced Quek 1/VEGFR2 and increased the addition of new HVC neurons in vivo (Hidalgo et al. 1995; Louissaint et al. 2002).

BDNF expression by HVC endothelial cells lags VEGF expression by 1 wk or more. Inhibition of VEGFR2 in vivo in HVC prevented both increased vasculature and neuronal addition, whereas treatment of cultured endothelial cells with $\mathrm{T}, \mathrm{E}_{2}$, or DHT increased production of BDNF protein (Louissaint et al. 2002). Together, these results suggest a serial activation pathway: $T$ is aromatized to $E_{2}$, which increases vascularization in HVC by increasing VEGFR2 expression in endothelial cells. The endothelial cells in the expanded vascular bed are then stimulated by $\mathrm{T}$ via VEGF binding to VEGRR2 to express BDNF. BDNF, in turn, increases the survival of new neurons as well as increasing song behavior (Louissaint et al. 2002).

\section{Effects of Neural Activity}

Activity within the circuit to which new neurons are added influences the incorporation and survival of these cells (Barnea and Pravosudov 2011). Singing behavior increases neuronal survival in HVC via increased BDNF mRNA and protein expression in the population of $\mathrm{HVC}_{\mathrm{RA}}$ neurons to which new neurons are added ( $\mathrm{Li}$ et al. 2000). BDNF expression correlates with the number of songs produced per unit time in male zebra finches and, as discussed above, this BDNF production supports neuronal survival. The number of new neurons added to the adult HVC of male canaries is correlated with individual differences in the average amount of song produced (Alvarez-Borda et al. 2002). Alternatively, deafening (i.e., loss of auditory neural activity) decreases neuronal addition to HVC and the auditory caudomedial nidopallium (NCM) in adult zebra finches (Wang et al. 1999; Pytte et al. 2010).

The addition of $\mathrm{HVC}_{\mathrm{RA}}$ projection neurons is influenced by the electrical activity of target 


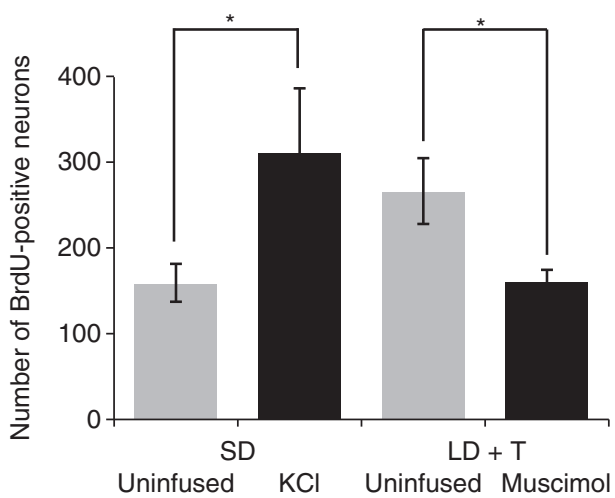

Figure 4. Postsynaptic activity influences the addition of new robust nucleus of the arcopallium (RA)-projecting neurons to HVC. Spontaneous activity of neurons in RA was decreased by unilateral infusions of muscimol $(2.8 \mathrm{mg} / \mathrm{ml})$ or increased by infusion of $\mathrm{KCl}(100 \mathrm{~mm})$. Inhibiting activity decreased neuronal addition (Larson et al. 2014). Increasing activity increased neuronal addition to $\mathrm{HVC}$ (ipsilateral to $\mathrm{KCl}$ infusion, $312 \pm 75$ new neurons; contralateral to $\mathrm{KCl}$ infusion, $160 \pm 23$ new neurons). Asterisks indicate $p<0.05$ in post hoc $t$-test following two-way ANOVA. BrdU, 5-bromo-2'-deoxyuridine; SD, short day; LD, long day; T, testosterone.

neurons in RA. The spontaneous activity of RA neurons is high in breeding sparrows and low in nonbreeding birds (Meitzen et al. 2007a,b, 2009a). Inhibiting activity in breeding-condition birds by infusing RA with the $\mathrm{GABA}_{\mathrm{A}}$ receptor agonist muscimol decreased the number of new neurons in HVC of adult white-crowned sparrows by 56\% (Fig. 4) (Larson et al. 2013). Increasing RA activity in nonbreeding condition birds by infusing $\mathrm{KCl}$ increased the number of new HVC neurons by 95\% (Fig. 4) (TA Larson, TW Wang, and EA Brenowitz, unpubl.). These results are consistent with the observation that activity is required for the survival of new neurons in the mammalian olfactory bulb (Corotto et al. 1994; Rochefort et al. 2002) and DG (Tashiro et al. 2006).

The mechanism by which activity influences neuronal addition to HVC is not yet known. Activity-induced regulation of genes encoding molecules that promote survival of adult-born HVC neurons, axonal path finding, and/or synapse formation is likely to be important (Zhang et al. 2001; Kay et al. 2011). Interestingly, activity-induced guidance molecules are seasonally regulated in RA neurons of white-crowned sparrows; microarray analysis of cDNA extracted from RA showed that the expression of axonal guidance cue genes, including netrin 4 and galectin, is increased in breeding-condition birds (Thompson et al. 2012). The retrograde transport of activity-induced trophic factors produced by target neurons that influence the survival of new $\mathrm{HVC}_{\mathrm{RA}}$ neurons may be modulated by activity in RA. Microarray analysis also showed that the expression of proneurogenic genes, including IGF-1 and neuromodulin, is increased in RA of breeding-condition birds (Thompson et al. 2012). In HVC, the expression of mRNA for sex steroid receptors, which facilitate the retrograde transport toward the neuronal soma of trophic factors bound to their receptor, also increases during breeding conditions (Fusani et al. 2000; Jezierski and Sohrabji 2003; Fraley et al. 2010). Once transported back to the soma, trophic factors likely activate signaling cascades that promote the growth and survival of new neurons (Gottschalk et al. 1999; Yoshii and Constantine-Paton 2007; EA Brenowitz, K Lent, R Luche, et al., unpubl). Inhibition of neural activity in RA may result in a failure of new HVC neurons to form synapses on RA neurons and/or a decreased production of activity-induced trophic factors in RA. The consequence would be a lack of retrograde transport of the trophic signals and, thus, a decrease in addition of adult-born neurons to HVC.

\section{Cell Death}

The addition of new neurons to HVC is functionally linked with the death of mature neurons. In adult male canaries, mature HVC neurons die when $\mathrm{T}$ levels decrease at the end of the breeding season. Within a few weeks, there is a peak in the addition of new neurons to HVC (Kirn et al. 1994). Laser photo-ablation of both $\mathrm{HVC}_{\mathrm{X}}$ and $\mathrm{HVC}_{\mathrm{RA}}$ projection neurons in adult male zebra finches increases the addition of new $\mathrm{HVC}_{\mathrm{RA}}$ neurons, but not of new $\mathrm{HVC}_{\mathrm{X}}$ neurons (Scharff et al. 2000). In adult 
Neurogenesis in Adult Birds

white-crowned sparrows, mature HVC neurons die seasonally through caspase-mediated apoptosis when T levels drop (Thompson and Brenowitz 2008). Reduction of this neuronal loss in HVC by infusion of a cocktail of caspase inhibitors reduces the number of new neurons added to HVC (Thompson and Brenowitz 2009). Within $2 \mathrm{~d}$ following the peak of cell death in HVC following the drop in T level, proliferation of neural progenitor cells in the VZ increases (Larson et al. 2014). These observations suggest that the death of mature neurons facilitates the addition of new neurons and, thus, apoptosis and neurogenesis may be causally linked. Consistent with this observation, in adult ring doves (Streptopelia risoria), lesion of the medial preoptic area of the hypothalamus (mPOA) induces neurogenesis in this region that does not normally add new neurons (Cheng et al. 2011). The molecular mechanisms linking cell death to neurogenesis are under investigation.
Age

Levels of neurogenesis decrease in the aging brain. In adult birds, the rates of neural progenitor cell proliferation (Larson et al. 2014), neuronal recruitment (Wilbrecht and Nottebohm 2004), and neuronal survival (Wang et al. 2002; Adar et al. 2008a) decrease with age across species. New neurons continue to be added to HVC, however, for as long as $11 \mathrm{yr}$ of age in zebra finches (Walton et al. 2012).

\section{Seasonality}

Most species of birds breed seasonally. In essentially every seasonally breeding songbird species that has been examined, there are pronounced seasonal changes in the morphology, electrophysiology, and gene expression of song nuclei (Fig. 5) (reviewed by Tramontin and Brenowitz 2000; Brenowitz 2008). These neural changes are accompanied by changes in song

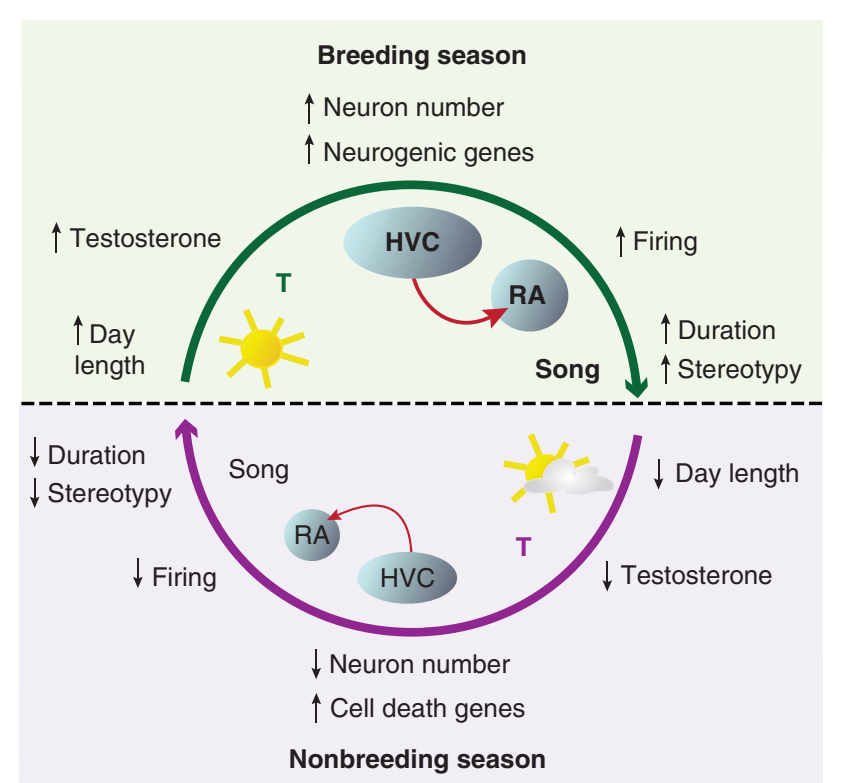

Figure 5. A model of the seasonal changes in physiology, morphology, and behavior of songbirds. As day length increases at the onset of the breeding season, plasma testosterone ( $\mathrm{T}$ ) levels increase. The increase in $\mathrm{T}$ drives an increase in neuronal number in HVC along with changes in gene expression, morphology, and physiology of HVC and robust nucleus of the arcopallium (RA). All of these changes in morphology and physiology permit the production of stereotyped song. As day length decreases at the onset of the nonbreeding season, T levels drop, HVC neurons die, and song degrades. This cycle repeats annually. 
rate and structure (Nottebohm and Nottebohm 1978; Smith et al. 1997). The seasonal changes in the song nuclei, all of which express androgen and/or estrogen receptors, are primarily regulated by changes in gonadal $\mathrm{T}$ and its metabolites (Brenowitz 2008).

Neuron number in HVC changes seasonally. In wild-caught song sparrows (Melospiza melodia), for example, neuron number in HVC increases from $\sim 150,000$ in the fall to 250,000 during the breeding season (Smith et al. 1997). This change in neuron number results from seasonal patterns of cell death and ongoing neurogenesis. At the end of the breeding season, circulating $\mathrm{T}$ levels decrease, which prompts an increase in the death of mature HVC neurons (Thompson et al. 2007; Thompson 2011). This death of mature HVC neurons during the transition from breeding to nonbreeding seasons creates "vacancies" for the addition of new neurons (Scharff et al. 2000; Nottebohm 2004; Thompson and Brenowitz 2009).

Field studies of wild birds show that growth of the song system occurs rapidly once plasma $\mathrm{T}$ levels first start to rise as day length increases in late winter, and precedes full seasonal reproductive development (Smith et al. 1997; Tramontin et al. 2001). In a laboratory study of captive white-crowned sparrows implanted with a systemic T implant and exposed to a long day photoperiod to mimic breeding conditions, HVC grew to its full breeding size and neuron number increased from 90,000 to 150,000 within $7 \mathrm{~d}$. This addition of 60,000 neurons to an adult brain within such a short time period is unprecedented.

As discussed above, the local expression of BDNF increases the survival of new HVC neurons. In a cDNA microarray hybridization study, Thompson et al. (2012) found that the gene for BDNF is significantly up-regulated in HVC following the transition of white-crowned sparrows from nonbreeding to breeding conditions. In situ hybridization measurements confirmed that BDNF mRNA is expressed widely throughout HVC of sparrows exposed to breeding conditions, and that expression increased over the $7 \mathrm{~d}$ following exposure to systemic $\mathrm{T}$ (Fig. 3) (Wissman and Brenowitz 2009).
When circulating $\mathrm{T}$ drops to basal levels at the end of the breeding season, mature HVC neurons lose the trophic support provided by T, BDNF, and the electrical activity of postsynaptic neurons in RA, and rapidly die (Rasika et al. 1994, 1999; Hidalgo et al. 1995; Brenowitz 2008; Thompson and Brenowitz 2010). Within $4 \mathrm{~d}$ of transferring white-crowned sparrows from breeding to nonbreeding conditions in the laboratory, 25\% of HVC neurons die (Thompson et al. 2007). The number of new neurons present in HVC increases following the death of mature neurons (Alvarez-Buylla et al. 1990; Tramontin and Brenowitz 1999). In the absence of trophic support, however, most of these new HVC neurons in nonbreeding birds do not persist in the song-control circuit. When two cohorts of new neurons were labeled by injections of 5-bromo- $2^{\prime}$-deoxyuridine (BrdU) and 5-ethynyl-2'-deoxyuridine (EdU) at different intervals, $>50 \%$ of the adult-born neurons present after $1 \mathrm{~m}$ in nonbreeding conditions belonged to the younger cohort of new neurons (TA Larson, NM Thatra, D Hou, EA Brenowitz, unpubl.). This result indicates that, in nonbreeding birds, many new HVC neurons are transient and are replaced by younger neurons. The turnover of new neurons continues until $\mathrm{T}$ levels start to rise early in the next breeding season. On transition into breeding conditions, the first cohort of neurons survived at a much higher rate when compared with nonbreeding conditions. Once HVC neuronal number stabilized at its maximum growth, subsequently added new neurons (i.e., the second cohort of labeled neurons) persisted at levels similar to nonbreeding condition. These observations suggest that the trophic cascade initiated by the increase in circulating $\mathrm{T}$ levels in breeding birds increases the survival of new neurons added during the initial growth of HVC, but does not affect neuronal turnover once HVC neuronal number stabilizes.

The HVC to RA circuit in white-crowned sparrows degenerates and is reconstructed seasonally. Over $50 \%$ of the $\mathrm{HVC}_{\mathrm{RA}}$ neurons die when sparrows transition from breeding to nonbreeding conditions (TA Larson, RE Cohen, MC Cole, et. al., unpubl.). Concomitant with 
this loss of projection neurons, song becomes less stereotyped and less complete in structure. The HVC to RA circuit is regenerated early the next breeding season when new neurons are integrated into HVC and grow their axons to synapse on RA neurons. The number of newborn $\mathrm{HVC}_{\mathrm{RA}}$ neurons increases by more than $300 \%$ in breeding birds. As the circuit is regenerated, sparrows are once again able to produce stereotyped and complete song. These data show that adult neurogenesis in the song system is restorative (sensu Gage et al. 2008).

\section{SOCIALITY (AND STRESS)}

Social setting may influence neuronal recruitment (reviewed in Gheusi et al. 2009). In the male zebra finch, a highly social species, social enrichment (i.e., group housing with male and female conspecifics) increases neuronal addition to HVC and other neurogenic regions of the brain including area X, NCM, and the HC, when compared with males housed alone or with a single female (Lipkind et al. 2002; Barnea et al. 2006; Adar et al. 2008a,b). The mechanism through which social enrichment promotes neuronal recruitment and survival in birds is unknown. Investigation of this topic should consider the possibility that what appears to be social enhancement of neurogenesis may actually reflect recovery from suppression of neurogenesis because of stress induced by housing birds in socially impoverished conditions. Stress-induced elevation of circulating glucocorticoid levels decreases the number of new neurons in the mammalian DG and the number of proliferating cells in the avian VZ (Westenbroek et al. 2004; Mirescu and Gould 2006; Katz et al. 2008). It is possible that elevated glucocorticoids caused by social stress could decrease neuronal proliferation and/or survival in birds.

\section{FUNCTIONS OF ADULT NEUROGENESIS}

Does the replacement of mature neurons with newborn neurons (i.e., neuronal turnover) in adult avian brains serve an adaptive function, and if so, what is it? As discussed below, various functional hypotheses can be proposed (Notte- bohm 1985, 2002; Wilbrecht and Kirn 2004; Barnea and Pravosudov 2011). These hypotheses are not necessarily mutually exclusive, and neurogenesis is likely to serve different functions in different taxa and different brain regions. A constraint on a discussion of possible function(s) of adult neurogenesis is that no studies that experimentally manipulate levels of neurogenesis in avian brain regions have yet been successfully conducted, and existing tests of hypotheses are, therefore, largely limited to correlational observations. Correlations typically have weak explanatory power by their nature. It is easy to confound correlation and causation, and difficult to determine the direction of causal relationships. As a consequence, no single hypothesis has yet received unambiguous support (Barnea and Pravosudov 2011). Any evaluation of different functional hypotheses is limited by these considerations. There is an urgent need to develop pharmacological or genetic methods of manipulating neuronal addition to adult brain regions to allow experimental tests of functional hypotheses.

\section{Neuronal Addition Is Vestigial}

The null hypothesis is that adult neurogenesis has no function in the avian brain. From this perspective, neurogenesis can be viewed as a vestige of developmental plasticity (Wilbrecht and Kirn 2004). The observation that levels of neurogenesis seen in the adult brain are much lower than those seen in developing brains is consistent with this hypothesis. If developmental neurogenesis persists into adulthood, however, we might expect to observe uniformly low levels of new neurons present throughout the adult brain. Contrary to this prediction, however, neurogenesis is widespread throughout the adult telencephalon, but is conspicuously absent from specific forebrain regions, such as the song nuclei RA and lateral magnocellular nucleus of the anterior neostriatum (LMAN). Furthermore, there is little adult neurogenesis outside the telencephalon (AlvarezBuylla et al. 1994). These observations suggest that neurogenesis can be selectively suppressed in adult brains and, therefore, that the presence 
of neurogenesis is likely the consequence of active maintenance rather than passive persistence.

Neuronal Turnover Allows Plasticity While Keeping Brain Size Small

Ongoing neuronal turnover in adult brains may represent a compromise between the need to continue to form and store new memories throughout the relatively long lifespans of songbirds ( 3 to $<10 \mathrm{yr}$ ), and the pronounced size and energetic constraints on brain size imposed by the demands of flight (Calder and King 1974). Replacing mature neurons with more plastic new neurons may be an avian alternative to the encephalization widely observed among mammals, especially those with enhanced cognition or social organization (Shultz and Dunbar 2010; Boddy et al. 2012). If individual neurons are viewed as the structural units of memory storage (e.g., Kempermann 2008), then neuronal turnover may allow a bird to continually encode new information while keeping absolute brain size relatively small (Nottebohm 2002, 2004). As is often true of evolutionary scenarios, a definitive test of this hypothesis would be challenging to conduct.

\section{Neuronal Turnover Enables Adult Birds to Learn to Produce New Songs}

The first demonstration of adult neurogenesis in songbirds was in the canary, a species that develops new motor patterns of song as an adult (Goldman and Nottebohm 1983). Nottebohm (1989) hypothesized that the addition of new neurons to HVC provides plasticity for encoding the memory of new song programs. Consistent with this model, neurons are added to HVC of adult canaries at a higher rate in the fall, when changes to song structure are most pronounced, than in the spring breeding season, when song structure is stable (Kirn et al. 1994). Further support for this model comes from the observation that new neurons are added to HVC of juvenile zebra finches at a high level while they are actively learning song, and at a lower level when song learning is completed (Nordeen and
Nordeen 1988; Wilbrecht et al. 2002). This decrease in neuronal addition can be delayed by isolating juvenile birds from adult male song tutors, which extends the sensitive period for song learning (Wilbrecht 2003).

Other observations, however, are inconsistent with this hypothesis. Even though the level of neuronal addition to HVC declines in zebra finches when song learning is completed, it does continue into adulthood after the birds have completed song learning. Like zebra finches, male song sparrows and white-crowned sparrows complete song learning in the first year of life, but continue to add new neurons to HVC and area X as adults (Tramontin and Brenowitz 1999; Thompson and Brenowitz 2009). As in canaries, wild song sparrows show higher levels of neuronal addition to HVC in the fall than in the spring, even though they retain the same songs throughout adulthood (Tramontin and Brenowitz 1999). The songs of both song sparrows and white-crowned sparrows, however, become variable in structure in the fall, as do those of canaries (Smith et al. 1995, 1997; Meitzen et al. 2009b). The loss of mature neurons that encode song, and addition of many new neurons that have not yet been "programmed" to produce the previously learned song, may contribute to the increased variability of song that sparrows sing during the fall. Together these observations suggest that, although neuronal turnover may be necessary or permissive for adult learning of new motor patterns of song, it is not sufficient to produce adult song learning.

\section{Neuronal Turnover Enables Adult Birds to Learn to Recognize New Songs}

Alternatively, neuronal addition may be a mechanism for acquiring new perceptual memories of song. New neurons are added to the auditory region NCM (Alvarez-Borda et al. 2002; Lipkind et al. 2002), as well as HVC and area X, each of which contributes to auditory discrimination of song (Brenowitz 1991; Scharff et al. 1998; Gentner et al. 2000). Both male and female birds learn to recognize the songs of individuals with whom they frequently interact; males can learn 
the individually distinctive songs of their immediate territorial neighbors (e.g., Stoddard et al. 1991) and females can recognize the songs of their mates (e.g., O'Loghlen and Beecher 1999). As birds may have a new neighbor or mate each year, the ability to update auditory song memories is advantageous. Neuronal turnover in auditory-responsive regions, such as HVC, area X, and NCM may provide a cellular mechanism for this perceptual plasticity (Wilbrecht and Kirn 2004). Support for this hypothesis comes from the observation that neuron number in HVC of juvenile swamp sparrows increases more during the early sensory phase of song learning, when adult song is heard and memorized, than during the later sensorimotor phase, when a juvenile begins to sing (Nordeen et al. 1989). If auditory experience influences neuronal addition, then deafening birds should disrupt this process. A decrease in neuronal addition to HVC was observed on deafening in adult (Wang et al. 1999) but not juvenile (Wilbrecht et al. 2002) zebra finches. The disparity between these deafening studies is difficult to explain. A direct test of the hypothesis that neuronal addition enables perceptual learning has not yet been performed. The observation that a bird's ability to form new auditory memories is impaired when neuronal addition is experimentally suppressed in adults would support this hypothesis.

\section{Neuronal Turnover Is Necessary for Song Maintenance}

Maintaining previously learned song in adults is an ongoing process, and the addition of new neurons to HVC and area X may provide cellular plasticity for continual updating of motor programs for song (Wilbrecht and Kirn 2004; Barnea and Pravosudov 2011). Disrupting auditory feedback can lead to degraded song structure in adult birds. Song begins to deteriorate within $1 \mathrm{wk}$ of deafening in Bengalese finches (Lonchura striata domestica) and after 2-8 wk in zebra finches, depending on their age (Nordeen and Nordeen 1992; Woolley and Rubel 1997; Lombardino and Nottebohm 2000). Exposing adult zebra finches to delayed auditory feedback similarly leads to song deterioration after several weeks (Leonardo and Kinishi 1999). Masking selected Bengalese finch song frequencies or disrupting auditory feedback in real time results in rapid changes in song structure (Sakata and Brainard 2006; Tumer and Brainard 2007). These observations indicate that birds need to hear themselves sing to maintain stereotyped song production as adults. Adult birds may compare ongoing auditory feedback from their song with a previously memorized sensory model of song (i.e., a "song template"). Alternatively, the song-control circuitry may generate an instructive signal that enables birds to adjust song as necessary to match a learned song production program (reviewed in Brainard 2008).

An essential component of error-correction models is that there is variability in song structure that can be exploited to allow birds to adjust song structure to more closely match a sensory template or learned motor program. The addition of many new HVC neurons that have not been programmed to produce a previously learned song may increase the variability of song and, thus, provide the raw material for error correction. The process of adjusting variable song to match a learned model may program new neurons to produce the appropriate premotor pattern. This function of adult neuronal turnover could be adaptive for the long-term maintenance of song in adults. A prediction of this hypothesis is that suppression of neuronal addition to HVC should result in a short-term decrease in song variability but a long-term progressive deviation of song structure away from the stereotyped version produced at the completion of juvenile song learning.

Alvarez-Borda et al. (2002) compared neuronal recruitment to HVC in gonadally intact and castrated male canaries that produced comparable amounts of song in the fall, when song becomes more variable. When matched for the amount of singing, the intact birds had $\sim 4$ times as many new RA-projecting neurons, and $\sim 2.6$ times as many total new HVC neurons as did the castrated birds. The investigators observed no difference between the intact and castrated birds in either the diversity of song syllables or song stereotypy, however, despite the pronounced 
differences in the addition of new neurons to HVC. These results do not support the hypothesis, although the manipulation of circulating testosterone levels is a considerable potential confound. A test of the hypothesis involving a more direct manipulation of neuronal addition to HVC is warranted.

\section{Neuronal Turnover Enables Adult Birds to Replace Overexcited Neurons}

Excessive activation of glutamate receptors by excitatory neurotransmission can result in cell death because of various factors, including disrupted intracellular calcium homeostasis, impaired organelle function, increased production of nitric oxide and free radicals, prolonged activation of proteases and kinases, and increased expression of proapoptotic transcription factors (Wang and Qin 2010). Neuronal addition to adult HVC may be an adaptation for replacing cells that are damaged by excitotoxicity and high metabolic demand resulting from prolonged activity (Wilbrecht and Kirn 2004).

During the breeding season, male birds can sing at extremely high rates and do so for several months consecutively. A territorial male redeyed vireo, for example, may sing more than 20,000 times a day (www.birds.cornell.edu). Individual $\mathrm{HVC}_{\mathrm{RA}}$ neurons fire at high rates in temporally sparse bursts of activity during singing (Hahn and Ball 1995; Fee et al. 2004), and these bursts can propagate through the $\mathrm{HVC}_{\mathrm{RA}}$ neuronal population via local excitatory synapses (Mooney and Prather 2005). $\mathrm{HVC}_{\mathrm{RA}}$ neurons stimulate excitatory postsynaptic potentials (EPSPs) via ionotropic glutamate receptors (Mooney and Prather 2005). Excitatory synaptic transmission between HVC neurons, and between HVC and RA neurons, also involves the activation of both AMPA/kainate and NMDA-type glutamate receptors (Dutar et al. 2000). Given the extraordinary high rate of song production, neuronal activation during the months-long breeding season should also be high. Supporting this assumption, the activity of cytochrome oxidase, an enzyme important in cellular oxidative metabolism, is higher in neurons of HVC, area X, and RA in breeding birds than nonbreeding birds, indicating that the metabolic demands of these neurons increase when birds sing at high rates (Wennstrom et al. 2001).

This hypothesis is further supported by several other observations. About $50 \%$ of the $\mathrm{HVC}_{\mathrm{RA}}$ neurons in adult male Gambel's whitecrowned sparrows die rapidly when testosterone levels decrease at the end of the breeding season (Thompson et al. 2007; Thompson and Brenowitz 2008, 2010; TA Larson, RE Cohen, MC Cole, et. al., unpubl.). This burst of neuronal death coincides with a reduction in trophic support provided both by testosterone and its downstream effectors as discussed above. $\mathrm{HVC}_{\mathrm{RA}}$ neurons and HVC interneurons that have been highly active during the preceding months may be especially prone to apoptosis from the cumulative detrimental effects of excitotoxicity and metabolic challenge in the absence of trophic support.

Other observations, however, do not support this hypothesis. Area $\mathrm{X}$ neurons also show high spontaneous and song-related activity, and receive glutamatergic inputs (Ding et al. 2003), but the rate of neuronal addition does not differ seasonally (Thompson and Brenowitz 2005). The neurons of RA also show high levels of activity, both spontaneous and evoked, during the breeding season (Fee et al. 2004; Meitzen et al. 2007b), and contain both AMPA/kainate and NMDA-type glutamate receptors (Wada et al. 2004). New neurons are not added to the adult RA, however. Motor neurons in $\mathrm{nXII}_{\mathrm{ts}}$ that innervate the muscles of the vocal organ are presumably driven at a high rate during the months of frequent song production in the breeding season, and contain NMDA receptors (Sturdy et al. 2003), but this nucleus also does not add neurons in adults. Together, these observations suggest that the anatomical distribution of neuronal addition in adult brains is not related to either the presence of ionotropic glutamatergic receptors or metabolic demand in an obvious manner (Nottebohm 2002).

A prediction of this hypothesis is that the death of mature neurons, and the addition of new neurons, would be reduced by protecting HVC neurons from glutamate-mediated excito- 
toxicity. Thus, this hypothesis could be tested by manipulations that protect HVC from metabolic damage, such as infusing HVC with exogenous acetoacetate, an energy substrate (Massieu et al. 2003), or overexpression of endogenous Sirt 3, a nicotinamide adenine nucleotide-dependent deacetylase (Kim et al. 2011), with a concomitant reduction in HVC neuronal death.

Adult-Born Neurons Replace Mature Neurons Weakened by Activity-Related DNA Damage

Neuronal activity, even at moderate levels, such as that involved in exploratory activity of mice, can result in DNA double-strand breaks (DSBs) in neuronal genomes (Suberbielle et al. 2013). Activity-related DSBs are exacerbated in J20 mice that express human amyloid- $\beta$ precursor protein, and blocking extrasynaptic NMDAtype glutamate receptors containing the NR2B subunit prevents amyloid- $\beta$ DSBs in neuronal cultures (Suberbielle et al. 2013). Amyloid- $\beta$ precursor protein is present in HVC neurons, and is expressed at higher levels in breedingcondition birds (Thompson et al. 2012). As discussed above, birds sing at very high rates over the months of the breeding season, and activity in HVC neurons is expected to be high during this period. Excitatory synaptic transmission between HVC neurons involve the activation of NMDA-type glutamate receptors (Dutar et al. 2000), which contain the NR2B subunit (Singh et al. 2000, 2003). Together, these observations raise the possibility that HVC neurons may experience high levels of DNA DSBs. Prolonged and recurrent DNA damage may make these neurons more susceptible to cell death when the trophic support provided by Tand its downstream effectors is withdrawn at the end of the breeding season. Neuronal addition to adult HVC may be an adaptation to replace mature neurons that have experienced high levels of DNA damage during the prolonged period of high song-related activity in breeding birds. As with the activity-based hypothesis, this hypothesis predicts that there should be a relationship between song production rate, DNA DSBs in HVC neurons, and neuronal turnover in HVC.
Neuronal Addition to HVC Is an Example of Performance-Associated Hypertrophy

The sustained peak performance of a seasonally predictable behavioral or physiological task is often preceded by growth of the organs and/ or tissues involved in performance of the task (Piersma and Lindstrom 1997). For example, the size of the gonads and other reproductive structures increases dramatically in preparation for the annual breeding season, and these organs regress when the breeding season is terminated. Preparatory changes, such as these are stimulated by seasonal environmental cues and mediated by neural and endocrine signaling mechanisms. The maintenance of fully grown organ systems and tissues is energetically expensive, and these systems therefore, regress when peak performance is not required (Gaunt et al. 1990).

In applying the principle of performanceassociated hypertrophy to seasonal cycles of neuronal turnover in HVC, one can make the following predictions. (1) Song performance should be maximal during the breeding season. This prediction is supported by data from canaries, white-crowned sparrows, and song sparrows among many other species. As described above, males of these species sing more stereotyped songs, and sing more frequently, during the breeding season. (2) Growth of the song nuclei should precede behavioral changes. In the study of Tramontin et al. (2000), the increase in neuron number in HVC observed in male white-crowned sparrows in breeding condition occurred within $7 \mathrm{~d}$ of exposure to a long day photoperiod and high T, whereas song stereotypy increased between 7 and $20 \mathrm{~d}$ (Tramontin et al. 2000). (3) Energetic costs of maintaining a fully developed song system throughout the nonbreeding season outweigh those associated with regrowing the song system each spring. The relative metabolic costs of maintaining and regrowing the song system each year are not yet known. The activity of cytochrome oxidase, an enzymatic marker of cellular metabolic capacity, increases considerably in HVC, RA, and area X of breeding-condition white-crowned sparrows (Wennstrom et al. 2001). This result suggests 
that the song system does impose a greater metabolic cost in its fully grown state than when regressed.

Changes in neuronal turnover in HVC, and plasticity of the song system in general, may be an adaptation to reduce the energetic costs imposed by the song system in the fall and winter. Outside the breeding season, males do not need to produce frequent, stereotyped song for mate attraction or territorial defense. In the fall and winter, birds may experience the energetic stress of migration, increased thermoregulatory demands, and decreased food availability. Songbirds are relatively small animals with large-surface-area-to-volume ratios and are, therefore, particularly subject to energetic constraints (Calder and King 1974). Given that the brain requires large amounts of energy to maintain signaling activities (see Ames 2000), regression of the song system outside the breeding season reduces the energetic costs imposed by the song nuclei. On balance, the reduced energy required by a regressed song system throughout the fall and winter may outweigh the energy required to regrow it the following spring.

\section{Neuronal Turnover in HVC Occurs When Trophic Support Is Withdrawn}

Most of the preceding hypotheses posit that neuronal turnover in HVC is functionally related to seasonal changes in motor or sensory aspects of song behavior. Plasticity in HVC may not be directly related to song, however. It may occur as a passive consequence of the sensitivity of HVC neurons to testosterone, its steroid metabolites, downstream trophic factors, such as BDNF, and signaling cascades that regulate phosphorylation of proteins related to cell proliferation, growth, and survival (Hidalgo et al. 1995; Dittrich et al. 1999; Hartog et al. 2009; Wissman and Brenowitz 2009; Chen et al. 2013; EA Brenowitz, unpubl.).

Increased circulating testosterone early in the breeding season initiates a trophic cascade that supports the survival of new neurons added to HVC (Rasika et al. 1994, 1999). As HVC grows, it provides transsynaptic trophic support to neurons in its efferent targets RA and area X (Brenowitz and Lent 2001, 2002; Meitzen et al. 2007a; Brenowitz 2008). At the end of the breeding season, circulating $\mathrm{T}$ decreases to basal levels and the trophic cascade is terminated. As trophic support is withdrawn, both mature and new HVC neurons undergo apoptosis (Thompson et al. 2007; Thompson and Brenowitz 2008, 2009, 2010; Larson et al. 2014). As neurons are lost from the $\mathrm{HVC} \rightarrow \mathrm{RA}$ projection, song becomes shorter and more variable in structure. However, as noted above, birds do not need to produce stereotyped song to attract mates or defend territories during the fall and winter, and there is, consequently, no ecological cost to degradation of either the song circuits or song behavior. New neurons enter HVC in nonbreeding birds, but most die within weeks as long as plasma $\mathrm{T}$ levels remain low, as discussed above (Larson et al. 2014).

In this model, changes in song behavior are a passive consequence of, rather than the driving force behind, plasticity of the song-control circuits. This model clarifies several inconsistencies with the above models. (1) The model suggests that neuronal turnover in HVC could occur regardless of whether or not adult birds develop new songs. Seasonal patterns of neuronal addition to adult HVC are observed both in species that do and do not learn new songs. (2) This model suggests that neuronal turnover could occur independent of neural activity. As discussed above, neurons in the song nuclei RA and $\mathrm{nXII}_{\mathrm{ts}}$ show high levels of activity when song is produced frequently during the breeding season, but new neurons are not added to these regions in adult birds. (3) This model also suggests that neuronal turnover is not just a consequence of cell death from excitotoxicity. HVC, RA, area X, and $\mathrm{nXII}_{\mathrm{ts}}$ all contain neurons with glutamate receptors, but adult-born neurons are only added to HVC and area X, and neuronal addition is only seasonal in HVC. To the extent that this model resolves some of the observations that are inconsistent with the other hypotheses presented above, it may provide the most parsimonious explanation of neuronal turnover in the adult HVC. 
Neuronal Turnover in the Hippocampus Enables Adult Birds to Form New Spatial Memories

The $\mathrm{HC}$ in birds is thought to play an important role in the formation of spatial memories in contexts including food hoarding, navigation, and migration (for review, see Barnea and Pravosudov 2011). Neuronal turnover in the adult HC may provide plasticity for encoding new spatial memories. New neurons added to the $\mathrm{HC}$ at different times may allow anatomical separation of memories formed at the different times (i.e., pattern separation [Clelland et al. 2009]). Hoshooley and Sherry (2007) measured food-caching behavior and neuronal addition to the $\mathrm{HC}$ in captive black-capped chickadees at four times of year. They found that food caching was greatest in October, and that neuronal recruitment to $\mathrm{HC} 1 \mathrm{wk}$ after BrdU injection reached a peak in January. Using a 6-wk post-BrdU survival time, Barnea and Nottebohm (1994) found neuronal addition to $\mathrm{HC}$ to be greatest in semicaptive blackcapped chickadees in October. Providing juvenile marsh tits the opportunity to cache food increased cell proliferation in the $\mathrm{VZ}$ of the $\mathrm{HC}$, compared with matched-age tits that were not allowed to cache food (Patel et al. 1997). Captive adult mountain chickadees allowed to store food had more new doublecortin-expressing $\left(\mathrm{DCX}^{+}\right)$neurons in $\mathrm{HC}$ than birds deprived of this experience; both captive groups, however, had lower numbers of $\mathrm{DCX}^{+}$neurons in $\mathrm{HC}$ than did wild chickadees (LaDage et al. 2010). Together, these studies suggest that neuronal addition to $\mathrm{HC}$ varies seasonally, roughly correlates with the time of greatest food caching and retrieval, and is influenced by experience in storing food.

Birds in many taxonomic groups are able to navigate over long distances. In some species, such as geese, juveniles learn the migratory route from their parents. Some birds migrate to the same destination with great accuracy, as in males that return to the same territory site each year. Other birds, such as homing pigeons are able to navigate over hundreds of miles to return to a home site. Successful navigation re- quires that birds learn the location of their home site with reference to various cues, such as geographic landmarks, magnetic fields, polarization of sunlight, and olfactory cues (reviewed in Bingman and Able 2002; Bingman et al. 2003, 2005). Hippocampal-dependent spatial learning is essential for such long-distance migration and navigation. Lesion of the $\mathrm{HC}$ in homing pigeons disrupts navigation based on landmarks and the formation of spatial maps (Bingman et al. 2003, 2005). The role of the $\mathrm{HC}$ in migration and navigation raises the hypothesis that neuronal addition provides plasticity for encoding spatial memories necessary for long-distance orientation. Migration may take several weeks and ongoing neuronal addition may enable pattern separation of the different spatial memories that must be stored during the successive stages of these journeys. LaDage et al. (2011) reported that there are more DCX ${ }^{+}$ adult-born neurons in the HC of a migratory subspecies of white-crowned sparrow than a nonmigratory subspecies. A potential confound of this study, however, is that migratory birds experience intense and prolonged physical exercise, which could influence one or more components of neuronal addition to the HC (Kempermann et al. 2010).

\section{SUMMARY}

The avian song-control system offers several advantages as a model for studying adult neurogenesis. These advantages include: (1) the dedication of the neurogenic nuclei HVC and area X to the control of learned song; (2) the incorporation of new long-range projection neurons into a premotor circuit; (3) quantitative levels of neuronal addition; (4) the role of neurogenesis in large-scale changes in neuron number in $\mathrm{HVC}$ and the regeneration of the $\mathrm{HVC} \rightarrow \mathrm{RA}$ circuit in seasonally breeding birds; and (5) rich opportunities for comparative studies to test the role of neurogenesis in regulating different aspects of learned song.

Proliferative cells that give rise to new neurons reside in "hotspots" in the walls of the lateral ventricle. Most of the neuroblasts that give rise to new HVC neurons adopt a multipolar 
phenotype and follow a wandering, tortuous route from the VZ to HVC. Steroid sex hormones secreted by the gonads support the survival of adult-born HVC neurons. These hormone effects are mediated by the expression of genes that encode trophic factors, neurite extension, and vascularization. The survival of new neurons is also increased by song-induced activation of HVC cells and the electrical activity of postsynaptic neurons in RA. There is a functional linkage between the death of mature HVC neurons and the birth of new neurons.

Most birds breed seasonally and there is pronounced seasonal plasticity of the song-control circuits. Increased circulating levels of T early in the breeding season initiate a trophic cascade that supports the survival of new neurons, total neuron number in HVC increases dramatically, and the $\mathrm{HVC} \rightarrow \mathrm{RA}$ circuit is regenerated. At the end of the breeding season, plasma T levels decrease, the trophic cascade is terminated, mature and new HVC neurons undergo apoptosis, and the $\mathrm{HVC} \rightarrow \mathrm{RA}$ circuit degenerates.

It is unclear what the adaptive function of neurogenesis is in the adult song-control system. Various functional hypotheses can be proposed, but none has received unambiguous support. A constraint is that no study has yet directly manipulated levels of neurogenesis. There is an urgent need to develop pharmacological or genetic methods of manipulating neuronal addition to adult brain regions to allow definitive tests of functional hypotheses.

\section{ACKNOWLEDGMENTS}

This work is supported by National Institutes of Health (NIH) Grants MH53032 and NS075331 to E.A.B. Our thanks to Gerd Kempermann for helpful editorial suggestions.

\section{REFERENCES}

Abrous DN, Wojtowicz JM. 2008. Neurogenesis and hippocampal memory system. In Adult neurogenesis (ed. Gage FH, Kempermann G, Song HJ), pp. 445-461. Cold Spring Harbor Laboratory Press, Cold Spring Harbor, NY.

Adar E, Nottebohm F, Barnea A. 2008a. The relationship between nature of social change, age, and position of new neurons and their survival in adult zebra finch brain. J Neurosci 28: 5394-5400.

Adar E, Lotem A, Barnea A. 2008b. The effect of social environment on singing behavior in the zebra finch (Taeniopygia guttata) and its implication for neuronal recruitment. Behav Brain Res 187: 178-184.

Altman J, Das GD. 1965. Autoradiographic and histological evidence of postnatal hippocampal neurogenesis in rats. J Comp Neurol 124: 319-335.

Alvarez-Borda B, Nottebohm F. 2002. Gonads and singing play separate, additive roles in new neuron recruitment in adult canary brain. J Neurosci 22: 8684-8690.

Alvarez-Borda B, Haripal B, Nottebohm F. 2004. Timing of brain-derived neurotrophic factor exposure affects life expectancy of new neurons. Proc Natl Acad Sci 101: 3957-3961.

Alvarez-Buylla A, Kirn JR. 1997. Birth, migration, incorporation, and death of vocal control neurons in adult songbirds. J Neurobiol 33: 585-601.

Alvarez-Buylla A, Nottebohm F. 1988. Migration of young neurons in adult avian brain. Nature 335: 353-354.

Alvarez-Buylla A, Kirn JR, Nottebohm F. 1990. Birth of projection neurons in adult avian brain may be related to perceptual or motor learning [ published erratum appears in Science 250: 360, 1990]. Science 249: 1444-1446.

Alvarez-Buylla A, Ling CY, Yu WS. 1994. Contribution of neurons born during embryonic, juvenile, and adult life to the brain of adult canaries: Regional specificity and delayed birth of neurons in the song-control nuclei. $J$ Comp Neurol 347: 233-248.

Alvarez-Buylla A, Seri B, Doetsch F. 2002. Identification of neural stem cells in the adult vertebrate brain. Brain Res Bull 57: 751-758.

Ames A III. 2000. CNS energy metabolism as related to function. Brain Res Brain Res Rev 34: 42-68.

Barami K, Kirschenbaum B, Lemmon V, Goldman SA. 1994. $\mathrm{N}$-cadherin and $\mathrm{Ng}-\mathrm{CAM} / 8 \mathrm{D} 9$ are involved serially in the migration of newly generated neurons into the adult songbird brain. Neuron 13: 567-582.

Barami K, Iversen K, Furneaux H, Goldman SA. 1995. Hu protein as an early marker of neuronal phenotypic differentiation by subependymal zone cells of the adult songbird forebrain. J Neurobiol 28: 82-101.

Barnea A, Nottebohm F. 1994. Seasonal recruitment of hippocampal neurons in adult free-ranging black-capped chickadees. Proc Natl Acad Sci 91: 11217-11221.

Barnea A, Pravosudov V. 2011. Birds as a model to study adult neurogenesis: Bridging evolutionary, comparative and neuroethological approaches. Eur J Neurosci 34: 884-907.

Barnea A, Mishal A, Nottebohm F. 2006. Social and spatial changes induce multiple survival regimes for new neurons in two regions of the adult brain: An anatomical representation of time? Behav Brain Res 167: 63-74.

Beecher MD, Brenowitz EA. 2005. Functional aspects of song learning in the songbirds. Trends Ecol Evol 20: $143-149$.

Bingman VP, Able KP. 2002. Maps in birds: Representational mechanisms and neural bases. Curr Opin Neurobiol 12: $745-750$. 
Bingman VP, Hough GE II, Kahn MC, Siegel JJ. 2003. The homing pigeon hippocampus and space: In search of adaptive specialization. Brain Behav Evol 62: 117-127.

Bingman VP, Gagliardo AA, Hough GE II, Ioale P, Kahn MC, Siegel JJ. 2005. The avian hippocampus, homing in pigeons and the memory representation of large-scale space. Integrat Comp Biol 45: 555-564.

Boddy AM, McGowen MR, Sherwood CC, Grossman LI, Goodman M, Wildman DE. 2012. Comparative analysis of encephalization in mammals reveals relaxed constraints on anthropoid primate and cetacean brain scaling. J Evol Biol 25: 981-994.

Brainard MS. 2008. The anterior forebrain pathway and vocal plasticity. In Neuroscience of birdsong (ed. Zeigler HP, Marler P), pp. 240-255. Cambridge University Press, Cambridge.

Brenowitz EA. 1991. Altered perception of species-specific song by female birds after lesions of a forebrain nucleus. Science 251: 303-305.

Brenowitz EA. 1997. Comparative approaches to the avian song system. J Neurobiol 33: 517-531.

Brenowitz EA. 2008. Plasticity of the song control system in adult birds. In Neuroscience of birdsong (ed. Zeigler HP, Marler P), pp. 332-349. Cambridge University Press, Cambridge.

Brenowitz EA, Beecher MD. 2005. Song learning in birds: Diversity and plasticity, opportunities and challenges. Trends Neurosci 28: 127-132.

Brenowitz EA, Lent K. 2001. Afferent input is necessary for seasonal growth and maintenance of adult avian song control circuits. J Neurosci 21: 2320-2329.

Brenowitz EA, Lent K. 2002. Act locally and think globally: Intracerebral testosterone implants induce seasonal-like growth of adult avian song control circuits. Proc Natl Acad Sci 99: 12421-12426.

Brown ES, Rush AJ, McEwen BS. 1999. Hippocampal remodeling and damage by corticosteroids: Implications for mood disorders. Neuropsychopharmacology 21: 474-484.

Burd GD, Nottebohm F. 1985. Ultrastructural characterization of synaptic terminals formed on newly generated neurons in a song control nucleus of the adult canary forebrain. J Comp Neurol 240: 143-152.

Calder WA, King JR. 1974. Thermal and caloric relations in birds. In Avian biology (ed. Farner DS, King JR, Parkes KC), pp. 259-413. Academic, New York.

Cameron HA, Gould E. 1994. Adult neurogenesis is regulated by adrenal steroids in the dentate gyrus. Neuroscience 61: 203-209.

Cameron HA, McKay RD. 2001. Adult neurogenesis produces a large pool of new granule cells in the dentate gyrus. J Comp Neurol 435: 406-417.

Chen Z, Ye R, Goldman SA. 2013. Testosterone modulation of angiogenesis and neurogenesis in the adult songbird brain. Neuroscience 239: 139-148.

Cheng MF, Alexander K, Zhou S, Bonder E, Chuang LS. 2011. Newborn GnRH neurons in the adult forebrain of the ring dove. Horm Behav 60: 94-104.

Clelland CD, Choi M, Romberg C, Clemenson GD Jr, Fragniere A, Tyers P, Jessberger S, Saksida LM, Barker RA, Gage FH, et al. 2009. A functional role for adult hippo- campal neurogenesis in spatial pattern separation. Science 325: 210-213.

Corotto FS, Henegar JR, Maruniak JA. 1994. Odor deprivation leads to reduced neurogenesis and reduced neuronal survival in the olfactory bulb of the adult mouse. Neuroscience 61: 739-744.

De Marchis S, Bovetti S, Carletti B, Hsieh YC, Garzotto D, Peretto P, Fasolo A, Puche AC, Rossi F. 2007. Generation of distinct types of periglomerular olfactory bulb interneurons during development and in adult mice: Implication for intrinsic properties of the subventricular zone progenitor population. J Neurosci 27: 657-664.

Ding L, Perkel DJ, Farries MA. 2003. Presynaptic depression of glutamatergic synaptic transmission by D1-like dopamine receptor activation in the avian basal ganglia. $J$ Neurosci 23: 6086-6095.

Dittrich F, Feng Y, Metzdorf R, Gahr M. 1999. Estrogeninducible, sex-specific expression of brain-derived neurotrophic factor mRNA in a forebrain song control nucleus of the juvenile zebra finch. Proc Natl Acad Sci 96: 8241-8246.

Dutar P, Petrozzino JJ, Vu HM, Schmidt MF, Perkel DJ. 2000. Slow synaptic inhibition mediated by metabotropic glutamate receptor activation of GIRK channels. J Neurophysiol 84: 2284-90.

Eriksson PS, Perfilieva E, Bjork-Eriksson T, Alborn AM, Nordborg C, Peterson DA, Gage FH. 1998. Neurogenesis in the adult human hippocampus. Nat Med 4: $1313-$ 1317.

Fee MS, Kozhevnikov AA, Hahnloser RH. 2004. Neural mechanisms of vocal sequence generation in the songbird. Ann NY Acad Sci 1016: 153-170.

Fraley GS, Steiner RA, Lent K, Brenowitz EA. 2010. Seasonal changes in androgen receptor mRNA in the brain of the white-crowned sparrow. Gen Comp Endocrinol 166: $66-71$.

Fusani L, Van't Hof T, Hutchison JB, Gahr M. 2000. Seasonal expression of androgen receptors, estrogen receptors, and aromatase in the canary brain in relation to circulating androgens and estrogens. J Neurobiol 43: 254-268.

Gage FH, Song H, Kempermann G. 2008. Adult neurogenesis: A prologue. In Adult neurogenesis (ed. Gage FH Song H, Kempermann G), pp. 1-5. Cold Spring Harbor Laboratory Press, Cold Spring Harbor, NY.

Gahr M, Garcia-Segura LM. 1996. Testosterone-dependent increase of gap-junctions in HVC neurons of adult female canaries. Brain Res 712: 69-73.

Gahr M, Leitner S, Fusani L, Rybak F. 2002. What is the adaptive role of neurogenesis in adult birds? Prog Brain Res 138: 233-254.

Gaunt AS, Hikida RS, Jehl JR, Fenbert L. 1990. Rapid atrophy and hypertrophy of an avian flight muscle. Auk 107: 649-659.

Gentner TQ, Hulse SH, Bentley GE, Ball GF. 2000. Individual vocal recognition and the effect of partial lesions to $\mathrm{HVc}$ on discrimination, learning, and categorization of conspecific song in adult songbirds. J Neurobiol 42: 117133.

Gheusi G, Ortega-Perez I, Murray K, Lledo PM. 2009. A niche for adult neurogenesis in social behavior. Behav Brain Res 200: $315-322$. 
Goldman SA. 1990. Neuronal development and migration in explant cultures of the adult canary forebrain. J Neurosci 10: 2931-2939.

Goldman SA, Nottebohm F. 1983. Neuronal production migration, and differentiation in a vocal control nucleus of the adult female canary brain. Proc Natl Acad Sci 80: 2390-2394.

Goldman SA, Lemmon V, Chin SS. 1993. Migration of newly generated neurons upon ependymally derived radial guide cells in explant cultures of the adult songbird forebrain. Glia 8: 150-160.

Goldman SA, Zukhar A, Barami K, Mikawa T, Niedzwiecki D. 1996. Ependymal/subependymal zone cells of postnatal and adult songbird brain generate both neurons and nonneuronal siblings in vitro and in vivo. J Neurobiol 30: $505-520$.

Gottschalk WA, Jiang H, Tartaglia N, Feng L, Figurov A, Lu B. 1999. Signaling mechanisms mediating BDNF modulation of synaptic plasticity in the hippocampus. Learn Mem 6: 243-256.

Gould E, McEwen BS, Tanapat P, Galea LA, Fuchs E. 1997. Neurogenesis in the dentate gyrus of the adult tree shrew is regulated by psychosocial stress and NMDA receptor activation. J Neurosci 17: 2492-2498.

Gould E, Reeves AJ, Fallah M, Tanapat P, Gross CG, Fuchs E. 1999a. Hippocampal neurogenesis in adult Old World primates. Proc Natl Acad Sci 96: 5263-5267.

Gould E, Beylin A, Tanapat P, Reeves A, Shors TJ. 1999b. Learning enhances adult neurogenesis in the hippocampal formation. Nat Neurosci 2: 260-265.

Gray GE, Sanes JR. 1992. Lineage of radial glia in the chicken optic tectum. Development 114: 271-283.

Gross CG. 2000. Neurogenesis in the adult brain: Death of a dogma. Nat Rev Neurosci 1: 67-73.

Hahn TP, Ball GF. 1995. Changes in brain GnRH associated with photorefractoriness in house sparrows (Passer domesticus). Gen Comp Endocrinol 99: 349-363.

Hartog TE, Dittrich F, Pieneman AW, Jansen RF, FranklVilches C, Lessmann V, Lilliehook C, Goldman SA, Gahr M. 2009. Brain-derived neurotrophic factor signaling in the HVC is required for testosterone-induced song of female canaries. J Neurosci 29: 15511-15519.

Hidalgo A, Barami K, Iversen K, Goldman SA. 1995. Estrogens and non-estrogenic ovarian influences combine to promote the recruitment and decrease the turnover of new neurons in the adult female canary brain. J Neurobiol 27: $470-487$.

Hoshooley JS, Phillmore LS, Sherry DF, Macdougall-Shackleton SA. 2007. Annual cycle of the black-capped chickadee: Seasonality of food storing and the hippocampus. Brain Behav Evol 69: 161-168.

Jabès A, Lavenex PB, Amaral DG, Lavenex P. 2010. Quantitative analysis of postnatal neurogenesis and neuron number in the macaque monkey dentate gyrus. Eur $J$ Neurosci 31: 273-285.

Jarvis ED. 2009. Evolution of the pallium in birds and reptiles. In New encyclopedia of neuroscience (ed. Binder MD, Hirokawa N, Windhorst U), pp. 1390-1400. SpringerVerlag, Berlin.
Jezierski MK, Sohrabji F. 2003. Estrogen enhances retrograde transport of brain-derived neurotrophic factor in the rodent forebrain. Endocrinology 144: 5022-5029.

Jiang J, McMurtry J, Niedzwiecki D, Goldman SA. 1998. Insulin-like growth factor-1 is a radial cell-associated neurotrophin that promotes neuronal recruitment from the adult songbird edpendyma/subependyma. J Neurobiol 36: 1-15.

Kaplan MS, Hinds JW. 1977. Neurogenesis in the adult rat: Electron microscopic analysis of light radioautographs. Science 197: 1092-1094.

Katz A, Mirzatoni A, Zhen Y, Schlinger BA. 2008. Sex differences in cell proliferation and glucocorticoid responsiveness in the zebra finch brain. Eur J Neurosci 28: 99106.

Kay L, Humphreys L, Eickholt BJ, Burrone J. 2011. Neuronal activity drives matching of pre- and postsynaptic function during synapse maturation. Nat Neurosci 14: $688-$ 690.

Kempermann G. 2008. The neurogenic reserve hypothesis: What is adult hippocampal neurogenesis good for? Trends Neurosci 31: 163-169.

Kempermann G, Fabel K, Ehninger D, Babu H, Leal-Galicia P, Garthe A, Wolf S. 2010. Why and how physical activity promotes experience-induced brain plasticity. Front Neurosci 4: 189.

Kim SH, Lu HF, Alano CC. 2011. Neuronal Sirt3 protects against excitotoxic injury in mouse cortical neuron culture. PLoS ONE 6: e14731.

Kirn JR, Alvarez-Buylla A, Nottebohm F. 1991. Production and survival of projection neurons in a forebrain vocal center of adult male canaries. J Neurosci 11: 1756-1762.

Kirn J, O'Loughlin B, Kasparian S, Nottebohm F. 1994. Cell death and neuronal recruitment in the high vocal center of adult male canaries are temporally related to changes in song. Proc Natl Acad Sci 91: 7844-7848.

Kirn JR, Fishman Y, Sasportas K, Alvarez-Buylla A, Nottebohm F. 1999. Fate of new neurons in adult canary high vocal center during the first 30 days after their formation. J Comp Neurol 411: 487-494.

Konkel A, Cohen NJ. 2009. Relational memory and the hippocampus: Representations and methods. Front Neurosci 3: $166-174$.

LaDage LD, Roth TC II, Fox RA, Pravosudov VV. 2010. Ecologically relevant spatial memory use modulates hippocampal neurogenesis. Proc Biol Sci 277: 1071-1079.

LaDage LD, Roth TC, Pravosudov VV. 2011. Hippocampal neurogenesis is associated with migratory behaviour in adult but not juvenile sparrows (Zonotrichia leucophrys ssp.). Proc R Soc B Biol Sci 278: 138-143.

Larson TA, Wang TW, Gale SD, Miller KE, Thatra NM, Caras ML, Perkel DJ, Brenowitz EA. 2013. Postsynaptic neural activity regulates neuronal addition in the adult avian song control system. Proc Natl Acad Sci 110: 1664016644.

Larson TA, Thatra NM, Lee BH, Brenowitz EA. 2014. Reactive neurogenesis in response to naturally occurring apoptosis in an adult brain. J Neurosci 34: 13066-13076.

Leonardo A, Konishi M. 1999. Decrystallization of adult birdsong by perturbation of auditory feedback. Nature 399: $466-470$. 
Li XC, Jarvis ED, Alvarez-Borda B, Lim DA, Nottebohm F 2000. A relationship between behavior, neurotrophin expression, and new neuron survival. Proc Natl Acad Sci 97: 8584-8589.

Lim DA, Fishell GJ, Alvarez-Buylla A. 1997. Postnatal mouse subventricular zone neuronal precursors can migrate and differentiate within multiple levels of the developing neuraxis. Proc Natl Acad Sci 94: 14832-14836.

Lipkind D, Nottebohm F, Rado R, Barnea A. 2002. Social change affects the survival of new neurons in the forebrain of adult songbirds. Behav Brain Res 133: 31-43.

Lledo PM, Alonso M, Grubb MS. 2006. Adult neurogenesis and functional plasticity in neuronal circuits. Nat Rev Neurosci 7: 179-193.

Lombardino AJ, Nottebohm F. 2000. Age at deafening affects the stability of learned song in adult male zebra finches. J Neurosci 20: 5054-5064.

Louissaint A Jr, Rao S, Leventhal C, Goldman SA. 2002. Coordinated interaction of neurogenesis and angiogenesis in the adult songbird brain. Neuron 34: 945-960.

Malberg JE, Eisch AJ, Nestler EJ, Duman RS. 2000. Chronic antidepressant treatment increases neurogenesis in adult rat hippocampus. J Neurosci 20: 9104-9110.

Massieu L, Haces ML, Montiel T, Hernández-Fonseca K. 2003. Acetoacetate protects hippocampal neurons against glutamate-mediated neuronal damage during glycolysis inhibition. Neuroscience 120: 365-378.

Meitzen J, Moore IT, Lent K, Brenowitz EA, Perkel DJ. 2007a. Steroid hormones act transsynaptically within the forebrain to regulate neuronal phenotype and song stereotypy. J Neurosci 27: 12045-12057.

Meitzen J, Perkel DJ, Brenowitz EA. 2007b. Seasonal changes in intrinsic electrophysiological activity of song control neurons in wild song sparrows. J Comp Physiol A Neuroethol Sens Neural Behav Physiol 193: 677-683.

Meitzen J, Weaver AL, Brenowitz EA, Perkel DJ. 2009a. Plastic and stable electrophysiological properties of adult avian forebrain song-control neurons across changing breeding conditions. J Neurosci 29: 6558-6567.

Meitzen J, Thompson CK, Choi H, Perkel DJ, Brenowitz EA. 2009b. Time course of changes in Gambel's whitecrowned sparrow song behavior following transitions in breeding condition. Hormones Behav 55: 217-227.

Mirescu C, Gould E. 2006. Stress and adult neurogenesis. Hippocampus 16: 233-238.

Mooney R, Prather JF. 2005. The HVC microcircuit: The synaptic basis for interactions between song motor and vocal plasticity pathways. J Neurosci 25: 1952-1964.

Morris RG. 2006. Elements of a neurobiological theory of hippocampal function: The role of synaptic plasticity, synaptic tagging and schemas. Eur J Neurosci 23: 28292846.

Nordeen KW, Nordeen EJ. 1988. Projection neurons within a vocal motor pathway are born during song learning in zebra finches. Nature 334: 149-151.

Nordeen KW, Nordeen EJ. 1992. Auditory feedback is necessary for the maintenance of stereotyped song in adult zebra finches. Behav Neural Biol 57: 58-66.

Nordeen KW, Marler P, Nordeen EJ. 1989. Addition of songrelated neurons in swamp sparrows coincides with mem- orization, not production, of learned songs. J Neurobiol 20: $651-661$.

Nottebohm F. 1985. Neuronal replacement in adulthood. Ann NY Acad Sci 457: 143-161.

Nottebohm F. 1989. From bird song to neurogenesis. Sci Am 260: 74-79.

Nottebohm F. 2002. Why are some neurons replaced in adult brain? J Neurosci 22: 624-628.

Nottebohm F. 2004. The road we travelled: Discovery, choreography, and significance of brain replaceable neurons. Ann NY Acad Sci 1016: 628-658.

Nottebohm F, Nottebohm ME. 1978. Relationship between song repertoire and age in the canary, Serinus canarius. Zeitschrift-fuer-Tierpsychologie 46: 298-305.

Nottebohm F, O'Loughlin B, Gould K, Yohay K, AlvarezBuylla A. 1994. The life span of new neurons in a song control nucleus of the adult canary brain depends on time of year when these cells are born. Proc Natl Acad Sci 91: 7849-7853.

O’Loghlen AL, Beecher MD. 1999. Mate, neighbour and stranger songs: A female song sparrow perspective. Anim Behav 58: 13-20.

Patel SN, Clayton NS, Krebs JR. 1997. Spatial learning induces neurogenesis in the avian brain. Behav Brain Res 89: $115-128$.

Paton JA, Nottebohm FN. 1984. Neurons generated in the adult brain are recruited into functional circuits. Science 225: $1046-1048$.

Piersma T, Lindstrom A. 1997. Rapid reversible changes in organ size as a component of adaptive behavior. Trends Ecol Evol 12: 134-138.

Pytte CL, Parent C, Wildstein S, Varghese C, Oberlander S. 2010. Deafening decreases neuronal incorporation in the zebra finch caudomedial nidopallium (NCM). Behav Brain Res 211: 141-147.

Rakic P. 1985. Limits of neurogenesis in primates. Science 227: $1054-1056$

Rasika S, Nottebohm F, Alvarez-Buylla A. 1994. Testosterone increases the recruitment and/or survival of new high vocal center neurons in adult female canaries. Proc Natl Acad Sci 91: 7854-7888.

Rasika S, Alvarez-Buylla A, Nottebohm F. 1999. BDNF mediates the effects of testosterone on the survival of new neurons in an adult brain. Neuron 22: 53-62.

Rochefort C, Gheusi G, Vincent JD, Lledo PM. 2002. Enriched odor exposure increases the number of newborn neurons in the adult olfactory bulb and improves odor memory. J Neurosci 22: 2679-2689.

Sakata JT, Brainard MS. 2006. Real-time contributions of auditory feedback to avian vocal motor control. J Neurosci 26: 9619-9628.

Scharff C, Nottebohm F, Cynx J. 1998. Conspecific and heterospecific song discrimination in male zebra finches with lesions in the anterior forebrain pathway. J Neurobiol 36: 81-90.

Scharff C, Kirn JR, Grossman M, Macklis JD, Nottebohm F. 2000. Targeted neuronal death affects neuronal replacement and vocal behavior in adult songbirds. Neuron 25: 481-492. 
Scott BB, Lois C. 2007. Developmental origin and identity of song system neurons born during vocal learning in songbirds. J Comp Neurol 502: 202-214.

Scott BB, Gardner T, Ji N, Fee MS, Lois C. 2012. Wandering neuronal migration in the postnatal vertebrate forebrain. J Neurosci 32: 1436-1446.

Scotto-Lomassese S, Rochefort C, Nshdejan A, Scharff C. 2007. HVC interneurons are not renewed in adult male zebra finches. Eur J Neurosci 25: 1663-1668.

Shultz S, Dunbar R. 2010. Encephalization is not a universal macroevolutionary phenomenon in mammals but is associated with sociality. Proc Natl Acad Sci 107: 21582 21586.

Singh TD, Basham ME, Nordeen EJ, Nordeen KW. 2000. Early sensory and hormonal experience modulate agerelated changes in NR2B mRNA within a forebrain region controlling avian vocal learning. J Neurobiol 44: 82-94.

Singh TD, Heinrich JE, Wissman AM, Brenowitz EA, Nordeen EJ, Nordeen KW. 2003. Seasonal regulation of NMDA receptor NR2B mRNA in the adult canary song system. J Neurobiol 54: 593-603.

Smith GT, Brenowitz EA, Wingfield JC, Baptista LF 1995. Seasonal changes in song nuclei and song behavior in Gambel's white-crowned sparrows. J Neurobiol 28: $114-125$.

Smith GT, Brenowitz EA, Beecher MD, Wingfield JC. 1997. Seasonal changes in testosterone, neural attributes of song control nuclei, and song structure in wild songbirds. J Neurosci 17: 6001-6010.

Spalding KL, Bergmann O, Alkass K, Bernard S, Salehpour M, Huttner HB, Boström E, Westerlund I, Vial C, et al. 2013. Dynamics of hippocampal neurogenesis in adult humans. Cell 153: 1219-1227.

Stoddard PK, Beecher MD, Horning CL, Campbell SE. 1991. Recognition of individual neighbors by song in the song sparrow, a species with song repertoires. Behav Ecol Sociobiol 29: 211-215.

Sturdy CB, Wild JM, Mooney R. 2003. Respiratory and telencephalic modulation of vocal motor neurons in the zebra finch. J Neurosci 23: 1072-1086.

Suberbielle E, Sanchez PE, Kravitz AV, Wang X, Ho K, Eilertson K, Devidze N, Kreitzer AC, Mucke L. 2013. Physiologic brain activity causes DNA double-strand breaks in neurons, with exacerbation by amyloid- $\beta$. Nat Neurosci 16: 613-621.

Tashiro A, Sandler VM, Toni N, Zhao C, Gage FH. 2006. NMDA-receptor-mediated, cell-specific integration of new neurons in adult dentate gyrus. Nature 442: 929933.

Thompson CK. 2011. Cell death and the song control system: A model for how sex steroid hormones regulate naturally occurring neurodegeneration. Dev Growth Differ 53: 213-224.

Thompson CK, Brenowitz EA. 2005. Seasonal change in neuron size and spacing but not neuronal recruitment in a basal ganglia nucleus in the avian song control system. J Comp Neurol 481: 276-283.

Thompson CK, Brenowitz EA. 2008. Caspase inhibitor infusion protects an avian song control circuit from seasonal-like neurodegeneration. J Neurosci 28: 71307136.

Thompson CK, Brenowitz EA. 2009. Neurogenesis in an adult avian song nucleus is reduced by decreasing caspase-mediated apoptosis. J Neurosci 29: 4586-4591.

Thompson CK, Brenowitz EA. 2010. Neuroprotective effects of testosterone in a naturally occurring model of neurodegeneration in the adult avian song control system. J Comp Neurol 518: 4760-4770.

Thompson CK, Bentley GE, Brenowitz EA. 2007. Rapid seasonal-like regression of the adult avian song control system. Proc Natl Acad Sci 104: 15520-15525.

Thompson CK, Meitzen J, Replogle K, Drnevich J, Lent KL, Wissman AM, Farin FM, Bammler TK, Beyer RP, Clayton DF, et al. 2012. Seasonal changes in patterns of gene expression in avian song control brain regions. PLOS ONE 7: e35119.

Toni N, Laplagne DA, Zhao C, Lombardi G, Ribak CE, Gage FH, Schinder AF. 2008. Neurons born in the adult dentate gyrus form functional synapses with target cells. Nat Neurosci 11: 901-907.

Tramontin AD, Brenowitz EA. 1999. A field study of seasonal neuronal incorporation into the song control system of a songbird that lacks adult song learning. J Neurobiol 40: 316-326.

Tramontin AD, Brenowitz EA. 2000. Seasonal plasticity in the adult brain. Trends Neurosci 23: 251-258.

Tramontin AD, Hartman VN, Brenowitz EA. 2000. Breeding conditions induce rapid and sequential growth in adult avian song control circuits: A model of seasonal plasticity in the brain. J Neurosci 20: 854-861.

Tramontin AD, Perfito N, Wingfield JC, Brenowitz EA. 2001. Seasonal growth of song control nuclei precedes seasonal reproductive development in wild adult song sparrows. Gen Comp Endocrinol 122: 1-9.

Tumer EC, Brainard MS. 2007. Performance variability enables adaptive plasticity of "crystallized" adult birdsong. Nature 450: 1240-1244.

Vellema M, Van der Linden A, Gahr M. 2010. Area-specific migration and recruitment of new neurons in the adult songbird brain. J Comp Neurol 518: 1442-1459.

Wada K, Sakaguchi H, Jarvis ED, Hagiwara M. 2004. Differential expression of glutamate receptors in avian neural pathways for learned vocalization. J Comp Neurol 476: 44-64.

Walton C, Pariser E, Nottebohm F. 2012. The zebra finch paradox: Song is little changed, but number of neurons doubles. J Neurosci 32: 761-774.

Wang Y, Qin AH. 2010. Molecular and cellular mechanisms of excitotoxic neuronal death. Apoptosis 15: $1382-1402$.

Wang N, Aviram R, Kirn JR. 1999. Deafening alters neuron turnover within the telencephalic motor pathway for song control in adult zebra finches. J Neurosci 19: 10554-10561.

Wang N, Hurley P, Pytte C, Kirn JR. 2002. Vocal control neuron incorporation decreases with age in the adult zebra finch. J Neurosci 22: 10864-10870.

Warren WC, Clayton DF, Ellegren H, Arnold AP, Hillier LW, Kunstner A, Searle S, White S, Vilella AJ, Fairley S, 
et al. 2010. The genome of a songbird. Nature 464: $757-762$.

Wennstrom KL, Reeves BJ, Brenowitz EA. 2001. Testosterone treatment increases the metabolic capacity of adult avian song control nuclei. J Neurobiol 48: 256-264.

Westenbroek C, Den Boer JA, Veenhuis M, Ter Horst GJ. 2004. Chronic stress and social housing differentially affect neurogenesis in male and female rats. Brain Res Bull 64: 303-308.

Wilbrecht L. 2003. "The recruitment of new neurons to the song system during the sensitive period for song learning in the zebra finch." PhD thesis, Rockefeller University, New York.

Wilbrecht L, Kirn JR. 2004. Neuron addition and loss in the song system: Regulation and function. Ann NY Acad Sci 1016: 659-683.

Wilbrecht L, Nottebohm F. 2004. Age and experience affect the recruitment of new neurons to the song system of zebra finches during the sensitive period for song learn- ing: Ditto for vocal learning in humans? Ann NY Acad Sci 1021: 404-409.

Wilbrecht L, Crionas A, Nottebohm F. 2002. Experience affects recruitment of new neurons but not adult neuron number. J Neurosci 22: 825-831.

Wissman AM, Brenowitz EA. 2009. The role of neurotrophins in the seasonal-like growth of the avian song control system. J Neurosci 29: 6461-6471.

Woolley SM, Rubel EW. 1997. Bengalese finches Lonchura Striata domestica depend upon auditory feedback for the maintenance of adult song. J Neurosci 17: 63806390.

Yoshii A, Constantine-Paton M. 2007. BDNF induces transport of PSD-95 to dendrites through PI3K-AKT signaling after NMDA receptor activation. Nat Neurosci 10: $702-$ 711.

Zhang Y, Tounekti O, Akerman B, Goodyer CG, LeBlanc A. 2001. 17- $\beta$-estradiol induces an inhibitor of active caspases. J Neurosci 21: RC176. 


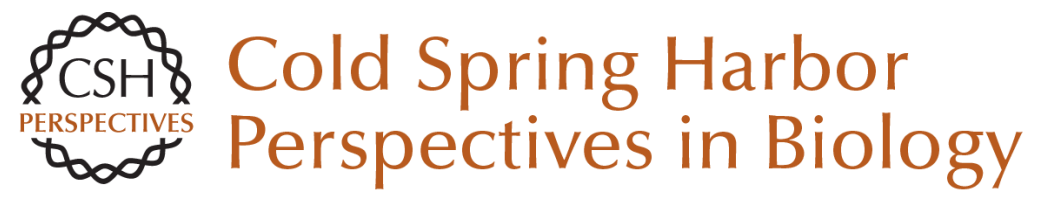

\section{Neurogenesis in the Adult Avian Song-Control System}

Eliot A. Brenowitz and Tracy A. Larson

Cold Spring Harb Perspect Biol 2015; doi: 10.1101/cshperspect.a019000

Subject Collection Neurogenesis

Adult Neurogenesis and Psychiatric Disorders Eunchai Kang, Zhexing Wen, Hongjun Song, et al.

Neuronal Circuitry Mechanisms Regulating Adult Mammalian Neurogenesis Juan Song, Reid H.J. Olsen, Jiaqi Sun, et al.

Neurogenesis in the Developing and Adult Brain

--Similarities and Key Differences Magdalena Götz, Masato Nakafuku and David Petrik

Genetics and Epigenetics in Adult Neurogenesis Jenny Hsieh and Xinyu Zhao

The Adult Ventricular-Subventricular Zone (V-SVZ) and Olfactory Bulb (OB) Neurogenesis Daniel A. Lim and Arturo Alvarez-Buylla

Diversity of Neural Precursors in the Adult Mammalian Brain Michael A. Bonaguidi, Ryan P. Stadel, Daniel A. Berg, et al.

Detection and Phenotypic Characterization of Adult Neurogenesis H. Georg Kuhn, Amelia J. Eisch, Kirsty Spalding, et al.

Maturation and Functional Integration of New Granule Cells into the Adult Hippocampus Nicolas Toni and Alejandro F. Schinder
Adult Olfactory Bulb Neurogenesis

Pierre-Marie Lledo and Matt Valley

Adult Neurogenesis in Fish Julia Ganz and Michael Brand

In Vitro Models for Neurogenesis Hassan Azari and Brent A. Reynolds

Engineering of Adult Neurogenesis and Gliogenesis

Benedikt Berninger and Sebastian Jessberger

Computational Modeling of Adult Neurogenesis James B. Aimone

Control of Adult Neurogenesis by Short-Range

Morphogenic-Signaling Molecules Youngshik Choe, Samuel J. Pleasure and Helena Mira

Adult Neurogenesis: An Evolutionary Perspective Gerd Kempermann

Epilepsy and Adult Neurogenesis

Sebastian Jessberger and Jack M. Parent

For additional articles in this collection, see http://cshperspectives.cshlp.org/cgi/collection/

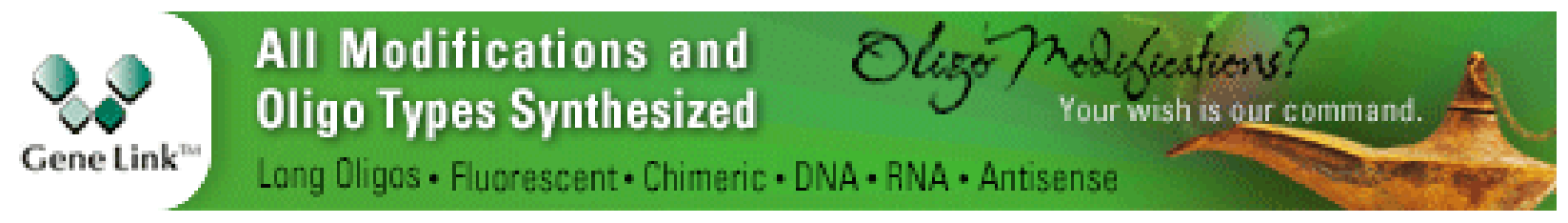

Copyright @ 2015 Cold Spring Harbor Laboratory Press; all rights reserved 